\title{
In Honor of Black History
}

On the occasion of Black History Month, February guest editor Talithia Williams presents a special section devoted to historical and contemporary figures and programs in math.

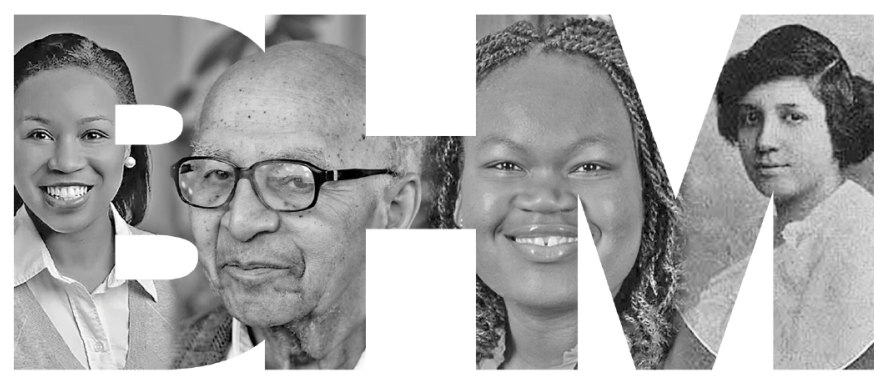

\section{Section Table of Contents:}

p. 119 Talithia Williams, "An Introduction"

p. 120 Arlie O. Petters, "Belonging"

p. 124 Erica Graham, Raegan Higgins, Candice Price, and Shelby Wilson, "The Mathematically Gifted and Black Website"

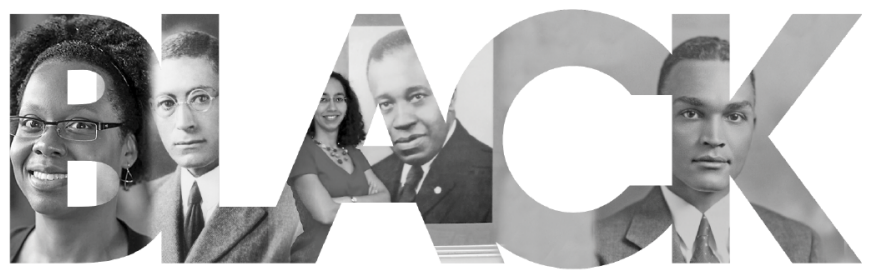

\section{Website}

p. 127 David Goldberg and Phil Kutzko, "The Math Alliance and Its Roots in the African American Community"

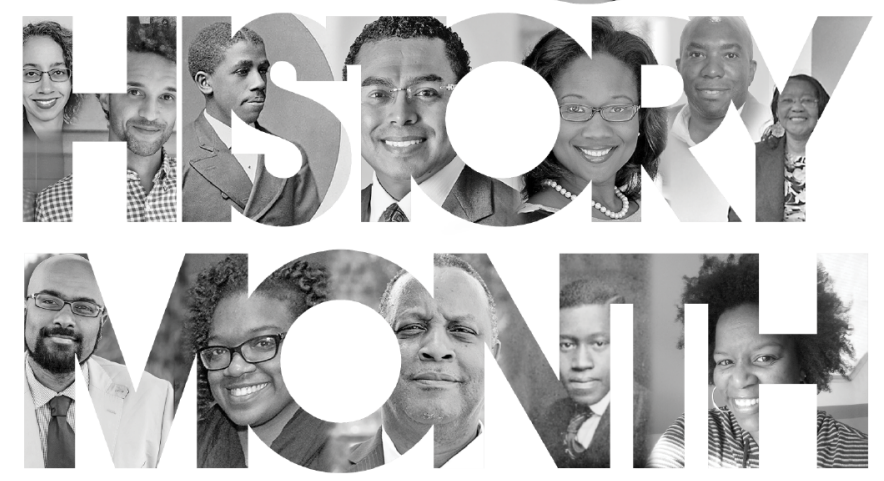

p. 132 Talitha M. Washington, "Behind Every Successful Woman, There Are a Few Good Men"

p. 135 Asamoah Nkwanta and Janet E. Barber, "Episodes in the Life of a Genius: J. Ernest Wilkins Jr."

p. 139 Johnny L. Houston, “Ten African American Pioneers and Mathematicians Who Inspired Me"

p. 144 Edray Herber Goins, "Three Questions: The Journey of One Black Mathematician"

p. 148 Talithia Williams, "Personal Conclusions"

p. 149 Vernon R. Morris and Talitha M. Washington, "The Role of Professional Societies in STEM Diversity" 


\section{An Introduction}

\section{Talithia Williams, Guest Editor}

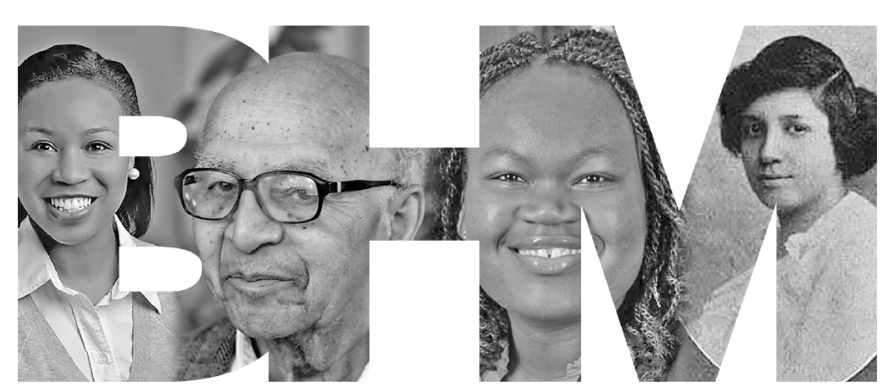

Black History Month was officially recognized by President Gerald Ford in 1976, when he encouraged the nation to "seize the opportunity to honor the too-often neglected accomplishments of Black Americans in every area of endeavor throughout our history." In celebration of Black History Month, we've chosen to highlight several experiences of African American mathematicians and programs that have worked to broaden participation in mathematics. Organizations such as the National Association of Mathematicians (NAM), the Enhancing Diversity in Graduate Education (EDGE) program, and Math Alliance are examples of go-to organizations for the mathematical development of underrepresented groups. Such organizations have worked to create inclusive mathematical communities and instill a sense of belonging to women and minorities, groups historically mathematically isolated.

If there's one word that summarizes the theme of this issue, it would be "Belonging." Arlie O. Petters, widely recognized as the founder of mathematical astronomy, discusses this foundational human need and how a sense of belonging allows all of us to maximize our excellence. Department chairs Asamoah Nkwanta and Janet Barber tell about the renowned genius J. Ernest Wilkins Jr. Johnny L. Houston, NAM co-founder and executive secretary from 1975 until 2000, shares "Ten African American Pioneers

Talithia Williams is associate professor of mathematics and associate dean for research and experiential learning at Harvey Mudd College. Her email address is twi11iams@g. hmc. edu.

For permission to reprint this article, please contact:

reprint-permission@ams.org. and Mathematicians Who Inspired Me." Its founders describe the Mathematically Gifted and Black website. Talitha Washington, member of the AMS Council, the AWM executive committee, and the NAM board, pays homage to the men who have nurtured her successful career as a mathematician, professor, and activist. NAM President Edray Herber Goins discusses three questions that have framed his personal journey. Directors David Goldberg and Phil Kutzko discuss the Math Alliance and its extraordinary contributions to the production of minority $\mathrm{PhDs}$.

During the past year, the movie Hidden Figures brought visibility to the lives of African American women mathematicians who served as NASA "human computers" in the 1960s. During that same time, Dr. Etta Falconer, the eleventh African American woman to receive a $\mathrm{PhD}$ in mathematics, began her tenure at Spelman College, motivating young women of color to be and do more than they dreamed possible in a field where their presence was lacking. Falconer was awarded the AWM Louise Hay Award in 1995 in honor of her outstanding achievements in mathematics education. Her response is a fitting tribute to those that continue to work to create mathematical communities in which all can thrive:

I have devoted my entire life to increasing the number of highly qualified African Americans in mathematics and mathematics related careers. High expectations, the building of self confidence, and the creation of a nurturing environment have been essential components for the success of these students. They have fully justified my beliefs. Perhaps the most rewarding moments have come when younger faculty have undertaken the same goal and have surpassed my efforts-reaching out to the broader community to help minorities and women achieve in mathematics. -Etta Falconer 


\section{Belonging}

\section{Arlie O.Petters}

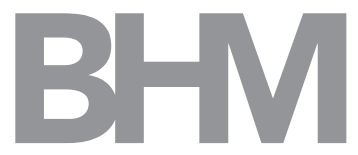

Belonging. What a word. What a deep-seated human need. It touches all of us, invoking a strong sense of loyalty and commitment when we are showered by it and feelings of alienation and distrust when it is denied. Julio Frenk, president of the University of Miami, deconstructed this word beautifully [2]:

The components of "belonging" are suggestive: "Be"-as in being-signifies authenticity and freedom from the need to cover aspects of one's identity. "Longing" reminds us of the profound human yearning to connect with others and be part of something that transcends us.

The times we live in have made this topic even more pressing. I shall discuss it within the context of underrepresented minorities and women in the mathematical sciences, though many of the ideas apply more broadly to the human experience. My goal is not to take you on an academic tour of the extensive psychology and sociology research literature on belonging. Instead, I will share some personal reflections and anecdotes intended to provide useful insights into the experiences of marginalized individuals.

\section{Othering and Such Climatic Joy Killers}

I remember being giddy with excitement to attend the welcoming reception for my entering class of math graduate students. I walked into the room and heads turned towards me. Feeling out of place, I walked over to two student-looking faces. One happened to be a fourth-year graduate math student and the other was a first-year like

Arlie O. Petters is Benjamin Powell Professor of Mathematics and professor of physics and economics at Duke University. His email address is ar1ie.petters@duke.edu.

For permission to reprint this article, please contact: reprint-permission@ams.org.

DOI: http://dx.doi.org/10.1090/noti1632 me. I introduced myself and, because I wanted a quick exit, I asked the more senior student how to get to the main math office. He told me that when I walked out the door, I should make a left, walk down the hallway, make another left, and it would be on my right. "Or, you could tie a rope to the ceiling and swing over to the other side," he said with a mischievous grin. The first-year student turned red with embarrassment. It did not matter whether the senior student thought of me as a monkey in a tree, Tarzan, or something else; his decision to engage in an unnecessary framing that could provoke a negative stereotype was telling. I quickly responded, "I see that you're going to be an a**hole," and I walked out of the room. Here I was, looking forward to being part of a new community of mathematicians and then being made to feel unwelcome at the onset.

I went directly to my apartment and started packing. My mind was racing and I was angry: "To hell with them. They turned around looking at me because I am a person of color. I am leaving this place. To hell with these people." As I started calming down, a counterintuitive thought occurred to me: "What if the others in the room weren't like him? What if they turned around and looked at me because they don't often see someone like me in an entering class and were curious to get to know me? ... If I leave, this guy will win. I refuse to let him win." My psychological bounce back was that he had brought the fight to me, and I refused to cower in fear or run away in anger. I had briefly allowed him to hijack and taint my perspective. And, even worse, by allowing him to make me angry, I had given him power over me in that moment. Never again. The emotional-intelligence battle was on. Would I have had such a fight-back spirit in the academic sphere if from pre-kindergarten my sense of self had been chipped away, bit by bit, by individual and 
institutional racism? I doubt it. Fortunately, I was raised until the age of fifteen years in Belize by a loving and resilient grandmother who strengthened me internally, fortifying my identity and allowing me to maintain its structural integrity in the face of undermining forces.

I was not naïve about the epiphany that caused me to stay. My hypothesis that most people in the room were not like him needed to be tested. But I had enough internal energy and grit to hold on to it by blind faith in the short term. The energy sustained me through the long hours of hard work needed to perform very well on my homework sets. And the grit enabled me to bear the anxiety that maybe most people in the environment did not really care for my being there and did not think much of me intellectually. In my case, I was fortunate to discover with time that most of the people were not like that graduate student. I had a perceptive and supportive thesis advisor and a positive interaction with the majority of the other math and physics graduate students and faculty. That young man had acted as if he owned the place. To me, he had a warped sense of belonging and entitlement that made him feel confident enough to treat me in a demeaning way without consequences.

I wish I could tell you that my experience was an anomaly. Over the years I have mentored a host of underrepresented minority students and listened to their experiences. They range from regular racial micro-aggression, through "oppressive othering," to more overt examples, like being the only one not invited to a bus outing organized by fellow math graduate students. A sense of belonging "involves one's personal belief that one is an accepted member of an academic community whose presence and contributions are valued" [3, p. 701]. This is important not only for the mathematics community but also for education and our society at large. At the convocation for Duke's entering 2017 undergraduate class, Stephen Nowicki emphasized to our students:

We only learn best from each other and teach each other well if we all feel like we belong. We can only achieve the excellence that lies in the potential of the different people and perspectives, the different aspirations and ideas we've brought together at Duke, if everyone feels equally that Duke belongs to them.

There's another important thing to understand about what it means to belong, which is that "belonging" does not mean "conforming." ... The excellence of this place emerges from the very different kinds of people who join our community. To diminish those differences through conformity would only diminish our excellence.

If we truly believe that diversity in all its dimensions is a key driver of excellence in our educational institutions and increases the probability of intellectual breakthroughs, then we cannot ignore the implicit biases directed toward underrepresented minorities and women. Actionable first steps a department can take as part of fostering a welcoming culture are to assign thoughtfully chosen mentors to incoming students and faculty; to advocate inclusion, acceptance, and understanding; and to promote effective ways to engage diversity. Imagine for a moment that you are a newcomer. Having someone in your department teach you the ropes and advise you from their own experiences is part of an onboarding that tells you from the beginning that you matter. Usually it is through such a relationship that your trust in the environment grows. By trust, I mean that you can allow yourself to be intellectually vulnerable without fear that your admission of the need for help or clarity will be attached to your race, ethnicity, gender identity, or social-class history. For example, you can feel secure enough to admit that you have certain gaps in your math background and allow the mentor to assist you with filling them. And you can ask faculty and seminar speakers questions about mathematical issues that are unclear to you.

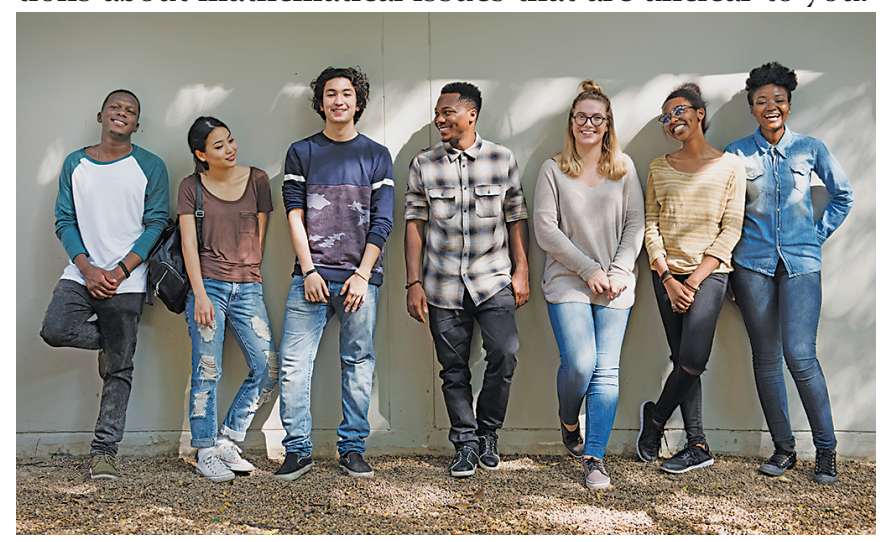

A diverse group of students exuding a sense of belonging.

\section{Deficit Thinking: Can They Add Value?}

Even when we accept diversity, it is still a problem when we approach it from a deficit-thinking perspective, that is, when we automatically expect lower achievement of students and even faculty from backgrounds that are not the norm. This brings me to an experience when I was inducted into Sigma Xi, the scientific research honor society. I felt so proud. Induction came with a really nice banquet. The guest speaker was the Queen of Carbon Science, Mildred Dresselhaus. At my table was an older Caucasian gentleman who seemed important through my student lens, at least as I inferred from his jacket and tie and the way he took control of our table. Going around the table, he started asking what research we were doing. I could not wait to tell him and the others about my work 
in mathematical physics. He asked everyone at the table about their work, except me. He made me feel as if I did not deserve to be in the honor society. It felt as if he were a displeased gatekeeper whose "boundary maintenance" was upset by my being admitted into the society. I had the last laugh, though. After Mildred spoke, I went up to her to introduce myself. She was welcoming and the first thing she wanted to know was, "What are you working on?" Mildred valued me enough intellectually to want to hear about my research.

Belonging involves more than the experience of feeling connected, welcomed, and free to be oneself. As underscored by psychologist Isaac Prilleltensky, another key part of belonging is being given the opportunity to add value. Imagine again that you are a newcomer. Even though everyone in your department is nice to you, if they do not see you as being able to add research value, you will likely not feel a sense of belonging. A simple practical gesture to improve belonging for underrepresented minorities and women in your department would be to talk with them about the mathematical research issues they are currently tackling and perhaps invite them to give a talk.

\section{No Organization Is Perfect, but Keep Improving}

I am sure that Sigma Xi would have been disappointed if they had learned about my induction experience. On August 28, 2017, the society issued its "Statement on Diversity and Recent Events in Charlottesville, Virginia." It pointed out that in May 1993 its leadership acknowledged that "the rich diversity of contemporary society was not reflected in the composition of the scientific and engineering communities, or in its own membership" and pledged "the Society to set aside barriers encountered by individuals from underrepresented groups who seek to become scientists and engineers, as well as to reach out to all members of our diverse society."

It is admirable to see the leaders of Sigma Xi acknowledge publicly that diversity within their organization is an important issue to address and then to act accordingly. In fact, some practical interventions on how to address belonging more broadly in one's department, institution, or organization are given in the intriguing paper [4]. And a very insightful analysis in the college context is in [1], including surveys that probe for belongingness and loneliness.

\section{It Is about Humility, My Friend}

There is a third aspect of belonging, which is important to unearth. It ties in with negative stereotypes about the value underrepresented minorities and women can contribute. To put it candidly, I am talking about views of math ability as innate versus acquirable through hard work, dedication, and practice. And I am not talking about the kind of nutty worldview of white supremacists that still echoes from the rally in Charlottesville, Virginia. I am talking about a subtler culture of how math ability is perceived.

In their revealing paper "Why do women opt out? Sense of belonging and women's representation in mathematics" the authors state [3, p. 700]:
Sense of belonging to math-one's feelings of membership and acceptance in the math domain-was established as a new and an important factor in the representation gap between males and females in math.... - the message that math ability is a fixed trait and the stereotype that women have less of this ability than men-worked together to erode women's, but not men's, sense of belonging in math. Their lowered sense of belonging, in turn, mediated women's desire to pursue math in the future and their math grades. Interestingly, the message that math ability could be acquired protected women from negative stereotypes, allowing them to maintain a high sense of belonging in math and the intention to pursue math in the future.

A similar statement about the mathematics representation gap between underrepresented minorities and whites would not come as a surprise. They continued [3, p. 701]:

Females who, despite the stereotype, find themselves in math-related disciplines must now face the "culture of talent" pervading these fields, a culture that may also undermine their sense of belonging. The United States and perhaps Western societies in general often view math ability as a talent, something that one is either born with or not.... In fact, individuals may often console themselves about their mathematics short-comings by falling back on the expression, "I'm not a math person." Perhaps nowhere is the belief in the fixed nature of math ability more entrenched than within the mathematics community itself, which relies on a 'talent-driven approach to math.' ... Research suggests that this mindset about the nature of intelligence as being a fixed trait (an "entity theory") can undermine achievement in the face of difficulty....

I have personally observed situations and heard anecdotes that are consistent with the above mindset about mathematics. It is then not unexpected to see "deficit thinking" often communicated in the attitudes of some towards underrepresented minorities and women in the mathematical sciences. And it is no surprise to see some marginalized students with high academic achievement in mathematics pursue careers in other fields. 


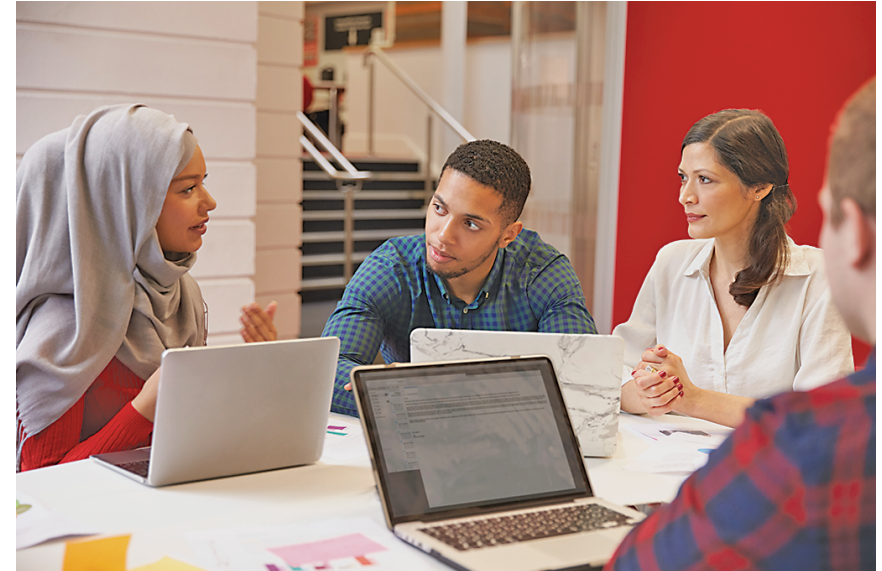

Students meeting for a tutorial with their instructor.

Every student has the capacity to succeed in mathematics. And, as with any challenging activity, we should purposefully emphasize that mathematics can be mastered through effort. Those who started delving into the subject from childhood, especially under the tutelage of a parent who is a mathematician, will naturally have an advantage in skill. But those who did not get such a head start can still fill their gaps and catch up on the fundamentals if they are deeply committed. Furthermore, the mathematical sciences have varied modes of reasoning, ranging from the algebraic to geometric, to analytic, to topological, to probabilistic, to statistical, to numerical, etc. This does not begin to touch on the interdisciplinary intuition employed in fields like mathematical physics, mathematical biology, mathematical finance, and so on. There is clearly room for a wide array of cognitive skills, and so some people will develop strengths in certain modes and intuitions over other ones. Equally important, we must also allow for the variations in learning styles that come with heterogeneity. Certain people will work best alone, others will excel with one or more co-authors, still others will flourish in large research collaborations. Such variety should be the spice of life in the mathematical sciences. Indeed, we must doggedly preserve this diversity and fight against any unhealthy mindset that promotes exclusion and a sense of superiority.

For many underrepresented minorities and women, the issue of belonging in mathematics has been a continued fundamental challenge. I believe that an integral part of keeping our field vibrant and relevant is for its participants to welcome everyone, knowing that anyone can get better at mathematics through an ample commitment of time and energy by teacher and student. Equally important, one should not only be welcoming at the door but also give people a chance to add value inside. Belonging is indeed a foundational human need, which when nurtured can bring out the best in all of us, enabling our community
ACKNOWLEDGMENT. I am indebted to Amir Aazami, Stanley Absher, John Blackshear, Kimberly Blackshear, Linda Burton, Patricia Hull, Elizabeth Petters, Molly Weeks, and Lee Willard for their invaluable feedback. And I especially would like to thank Molly and Linda for guiding me with the research literature on belonging and inequality.

to maximize its excellence. In the end, mathematicians are the custodians of mathematics. The onus is on us.

\section{References}

[1] S. ASHER and M. WEEKS, Loneliness and belongingness in the college years, Handbook of Solitude: Psychological Perspectives on Social Isolation, Social Withdrawal, and Being Alone, 283-301, Wiley, 2014.

[2] J. Frenk, Why We Need a 'Scholarship of Belonging,' The Chronicle of Higher Education (May 15, 2016).

[3] C. Good, A. RATTAN, and C. DwECK, Why Do Women Opt Out? Sense of Belonging and Women's Representation in Mathematics, J. Pers. Soc. Psychol.102 (2012), 700-717.

[4] G. WALTON and S. BRADY, The Many Questions of Belonging, Handbook of Competence and Motivation: Theory and Application, 272-293, Guilford Press, 2017.

\section{Photo Credits}

Photo of a diverse group of students by RAWPIXEL, courtesy of iStock by Getty Images.

Photo of students meeting with their instructor by monkeybusinessimages, courtesy of iStock by Getty Images.

Author photo courtesy of Arlie O. Petters.

\section{ABOUT THE AUTHOR}

Arlie O. Petters is an applied mathematician and mathematical physicist at Duke University. His primary research deals with how gravity acts on light. He also has an interest in mathematical finance and co-authored a textbook on the subject. Petters enjoys movies and music and is currently writing a science

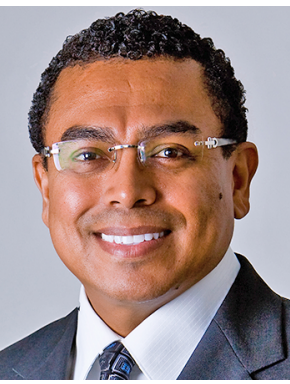
Arlie O. Petters fiction novel. 


\section{The Mathematically Gifted and Black Website}

\section{Erica Graham, Raegan Higgins, Candice Price, Shelby Wilson}

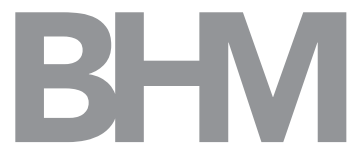

Mathematically Gifted and Black $(\mathrm{MGB})^{1}$ is a website to celebrate the diversity of Black mathematicians, highlighting their contributions to the mathematical sciences and community. First came lathisms.org, a website celebrating Hispanic Heritage Month. Next came the Academy Award-nominated film, Hidden Figures, which focused on three Black female mathematicians and their experiences at NASA. With such inspiration, we created a website for Black History Month, February 2017. We reached out to twenty-four Black mathematicians who are well known for their contributions to research, education, industry, government, academia, and outreach. We also selected an additional four "rising stars" contributing to multiple facets of the mathematical

community early in their careers. (See Figures 1-4.) The response was overwhelming, with the website shared on Twitter, Facebook ${ }^{2}$, classroom walls, office doors, and even The New York Times.

Erica Graham is assistant professor of mathematics at Bryn Mawr College. Her email address is ejgraham@brynmawr. edu. Raegan Higgins is associate professor of mathematics at Texas Tech University. Her email address is raegan. higgins@ttu. edu. Candice Price is assistant professor of mathematics at the University of San Diego. Her email address is cprice@sandi ego. edu. Shelby Wilson is assistant professor of mathematics at Morehouse College. Her email address is she1by.wi 1son@morehouse.edu.

www. mathematica11ygiftedandb1ack.com

${ }^{2}$ See the Facebook group "The Network of Minorities in Mathematical Sciences."

For permission to reprint this article, please contact:

reprint-permission@ams . org.

DOI: http://dx.doi.org/10.1090/noti1633
In selecting the twenty-four Black mathematicians, we relied heavily on our personal networks and on websites such as "Mathematicians of the African Diaspora." Those featured on the website must have a degree in mathematics and use it in their work. To generate a wellrounded profile group, we sought leaders in research, education, industry, government, academia, and outreach. The academy is represented by professors ranging from

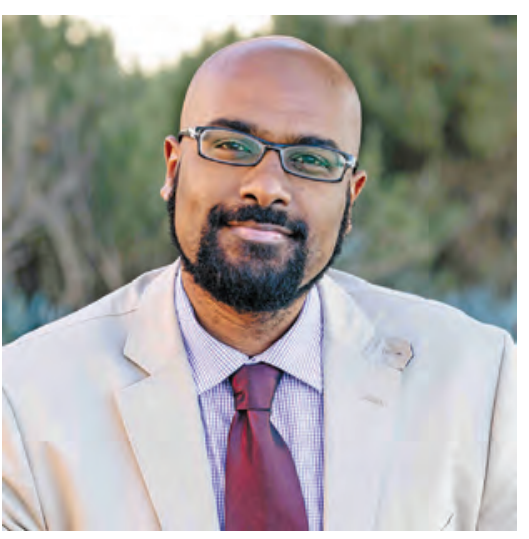

Figure 1: Mohamed Omar, assistant professor at Harvey Mudd College, was featured on the website on February 4, 2017. Besides teaching his students, Omar spreads his love and knowledge of mathematics to all via www. you tube. com/ MohamedOmarMath. research universities to liberal arts institutions. The highest ranks in the federal government are represented as well as business owners, military leaders, and innovators of technology. Higgins noted:

We found it very difficult to find people in leadership roles in academia with math degrees. There are very few deans, provosts, and college or university presidents that fit our criteria. But this was not much of a shock to us. We recognize that there are many barriers that Black mathematicians are still breaking down. What we hope is that we have highlighted some of the future deans, provosts and presidents, those that will break down those barriers. 


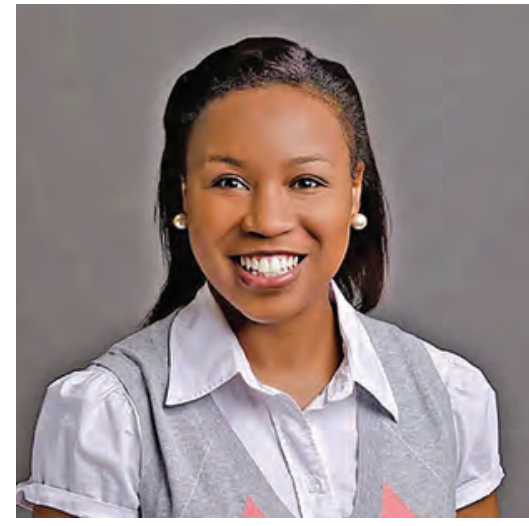

Figure 2: Talea Mayo, assistant professor at the University of Central Florida, was featured on the website on

February 11,2017.

Mayo specializes in coastal ocean modeling, with a special interest in hurricane storm surge, work that definitely came in handy this hurricane season.

tion about the 2017 profiles, Wilson shared:

One thing I noticed from many of these profiles is the idea that it wasn't a given that they would be good at mathematics, that it would be their career choice. For some, there wasn't this belief in their innate ability to do mathematics. They struggled and sought support, just as many of us do.

So what is next? While the website will continue to spotlight the contributions of a different Black mathematician every day in February, there is a plan to utilize the website in different ways during the rest of the year. We'd like to showcase programs like EDGE and SIAM WCD that support Black mathematicians and create strong research, social, and teaching networks. We'd also like to enhance the historical content on the website, emphasizing the contributions of Black mathematicians to research, education, teaching, outreach, government, and industry.

The power of the personal story is helping people better understand one another and shred stereotypes. The mathematicians spotlighted were able to tell their stories in their own words, to discuss their proudest moments, in mathematics and in life, and to include personal stories of struggle along with inspirational anecdotes. All were allowed to be themselves, unapologetically.

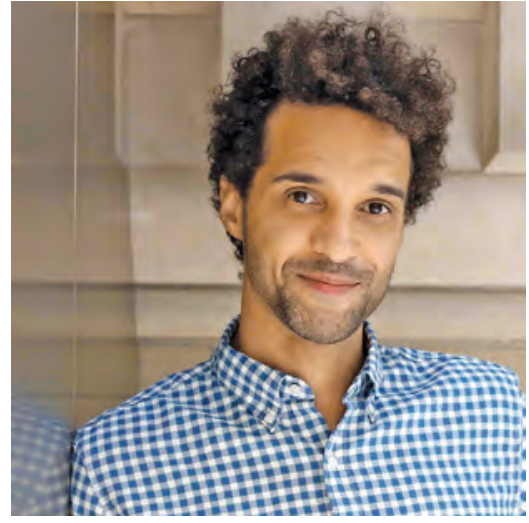

Figure 3: Ryan Hynd, assistant professor at the University of Pennsylvania, was featured on the website on February 18, 2017. This photo was taken of Hynd while he was visiting MIT as Martin Luther King Visiting Professor.

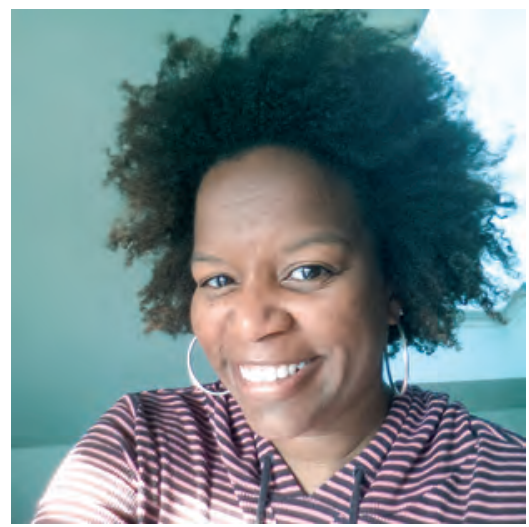

Figure 4: Chelsea Walton, Selma Lee Bloch Brown Assistant Professor at Temple University, in transition to the University of Illinois-Urbana Champaign, was featured on the website February 25, 2017. Walton was awarded a Sloan Fellowship in 2017.

\section{Photo Credits}

Figure 1 courtesy of Mohamed Omar. Figure 2 courtesy of Talea Mayo.

Figure 3 courtesy of Allegra Boverman. Figure 4 courtesy of Chelsea Walton.

Photo of Erica Graham courtesy of Aaron Windhorst/Bryn Mawr College.

Photo of Raegan Higgin courtesy of Raegan Higgins.

Photo of Candice Price courtesy of USMA DPTMS.

Photo of Shelby Wilson courtesy of Shelby Wilson. 


\section{BLACK HISTORY MONTH}

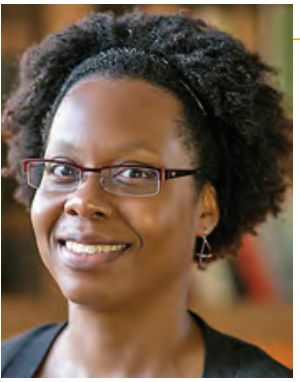

Erica Graham

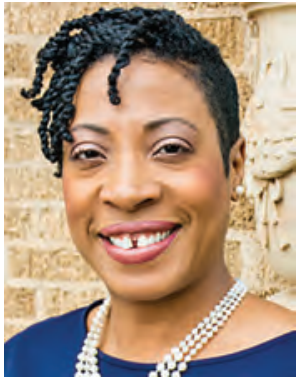

Raegan Higgins

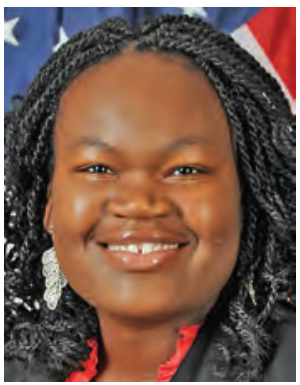

Candice Price

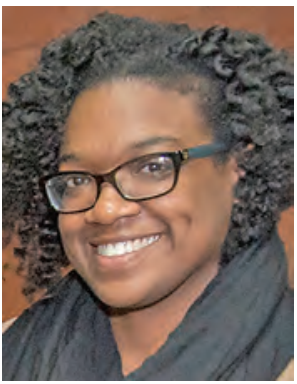

Shelby Wilson

\section{ABOUT THE AUTHORS}

Erica Graham does research in mathematical biology with applications to endocrinology. Current research includes reproductive hormone regulation and metabolic factors associated with ovulatory dysfunction.

\section{Raegan Higgins's research is in} time scales; her interests focus on oscillation criteria for second-order dynamic equations. Currently, she is studying applications of time scales to biology. Raegan volunteers in Mentor Tech at TTU and serves as president of the Lubbock Alumnae Chapter of Delta Sigma Theta Sorority, Inc.

Candice Price's service mission statement is to create and contribute to programs that broaden the participation of underrepresented groups by focusing on strong mentoring and research networks.

Shelby Wilson's research is in the area of mathematical biology and focuses on modeling with applications to medical sciences, immunology, and cancer. In her scant spare time, she loves to read, travel, and eat amazing food. 


\title{
The Math Alliance and Its Roots in the African American Community
}

\author{
David Goldberg and Phil Kutzko
}

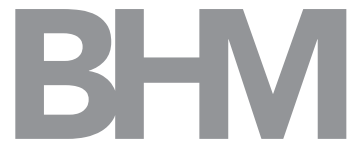

The Math Alliance, a national community of math sciences faculty committed to increasing the number of doctoral degrees awarded in those fields to underrepresented minority students, began in 1995 at the math department at the University of Iowa. In 2016 it moved to the College of Science at Purdue University. Math Alliance Executive Director David Goldberg and Math Alliance Director Phil Kutzko sat down to discuss the history of the Alliance and its relationship to the African American community.

EDITOR'S NOTE. In 2017 the Math Alliance won the AMS Award for Mathematics Programs That Make a Difference. ${ }^{1}$ In 2014 Philip Kutzko received the AMS Award for Distinguished Public Service. ${ }^{2}$

Goldberg: When you and your colleagues began your initiative at the University of Iowa, I don't think many folks would have bet on its success. And yet, twenty-two years later, thirty-four minority students have received $\mathrm{PhDs}$ from your department, including nine African Americans, and the Alliance has exceeded all expectations. How can you explain this?

Kutzko: It is actually hard to explain. If you'd have told me back then that a largely white department at a predominantly white university in a definitively white state

David Goldberg is executive director of the Math Alliance. His email address is goldbergapurdue. edu.

Phil Kutzko is director of the Math Alliance. His email address is Phi1ip-kutzko@uiowa.edu.

${ }^{1}$ See www.ams.org/publications/journals/notices/201705/ rnoti-p476.pdf.

${ }^{2}$ See www . ams . org/notices/201404/rnoti-p409.pdf.

For permission to reprint this article, please contact:

reprint-permission@ams .org.

DOI: http://dx.doi.org/10.1090/noti1635

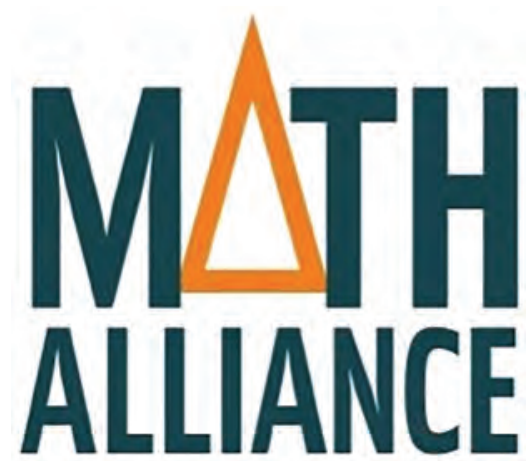

would have this kind of success, I would have wondered if we were living in the same country. And yet, if we are going to institutionalize this success we must try to understand the factors that led to it. One factor was the group of faculty at Iowa who started this initiative. We were about fifteen percent of the faculty, but we were all tenured, and most of us had good research credentials. We counted among our group our chair and our director of graduate studies. So those faculty in our department who were skeptical of what we were trying to do-and there were many-were inclined to let us give it a try. A second factor is that we all mentored. In fact, our department had always had a culture of mentoring, although I don't think we called it that or talked about it much before our initiative. These two factors, a critical mass of faculty and a culture of mentoring, formed the basis of our Alliance Graduate Program Groups.

Goldberg: Our department at Purdue was watching the developments at Iowa with great interest. There was a small group of Purdue math faculty who were interested in trying to change the demographics of the graduate student population and, more importantly, in trying to improve the experience for underrepresented minority students in our program. We adopted some of the mentoring structures from Iowa, and several faculty engaged in a program to recruit more thoroughly from minority-serving institutions.

Kutzko: How did it go?

Goldberg: The early results were mixed at best. Our department received its first GAANN grant in 2000 and was successful in attracting six underrepresented minority students to the program. Two of these students received PhDs, but the faculty mentors were not always successful in protecting them from painful experiences. Our colleagues at minority-serving institutions who had entrusted 


\section{"The Alliance has exceeded all expectations."}

their students to us were disappointed. Like many well-meaning departments, we found ourselves more part of the problem than the solution.

Kutzko: I always worried that that might happen with us. We had heard of so many departments who had begun to question whether the benefits of sending students to graduate schools at departments like ours was worth the risk.

Goldberg: How did you avoid this situation?

Kutzko: A lot of it was dumb luck! One of our original group, Herb Hethcote, was a colleague of Carlos Castillo-Chavez, and Carlos began to send us alumni of his MTBI program. Carlos was, even then, an important leader in the work we do, and he was very clear in his expectations of us. Most of our early PhDs were recommended to us by Carlos; eleven of our first twelve PhDs were Latinos.

Goldberg: It is interesting that, since that time, about thirty-five percent of your minority PhDs have been African American. Did you do something intentional to increase your numbers of African Americans?

Kutzko: Yes, we did, and this led to our original Alliance. The story is a good one. Sometime in 2001, Gene Madison $^{3}$ and I were at a social occasion in Iowa City and we were discussing, over a game of Bid Whist, ${ }^{4}$ the fact that our minority grad students up to that point had been overwhelmingly Latino. It turned out that another player at our table had gone to Florida Agricultural and Mechanical University (FAMU) and had a sister who was friends with Roselyn Williams, the FAMU math department chair. Gene and I went down to FAMU about two weeks later. We agreed that we would form an Alliance-the Alliance for the Production of African American PhDs in the Mathematical Sciences, that Roselyn would recruit representatives of three other Historically Black Colleges and Universities (HBCUs), that Gene and I would reach out to the math sciences departments at the three Iowa State Regents universities, and that we would meet again. We returned to FAMU with seven or eight faculty in the math sciences at all three of the Iowa schools and met there with faculty from our new HBCU partners: Benedict College, Alabama A\&M University, and Jackson State University, in addition to FAMU. We came up with a detailed plan and drafted a proposal to the Division of Math Sciences (DMS) at NSF.

\footnotetext{
${ }^{3}$ Eugene Madison, now retired, was professor of mathematics at the University of Iowa and among the first African Americans to hold such a post. He played a critical role in the UI math department's graduate minority initiative.

${ }^{4}$ For more on this card game popular among African Americans, see the NPR "...Story of Bid Whist" at www.npr.org/templates/ story/story.php?storyId=5069913.
}

Goldberg: I am assuming you were funded.

Kutzko: Not at first! Our initial proposal was rejected due to some strongly negative comments about HBCUs on the part of one of the reviewers. However, we were very fortunate that Philippe Tondeur, professor of mathematics at the University of Illinois, was the director of DMS. Tondeur encouraged us to apply again and to make the case for HBCUs. We were funded on our second try.

Goldberg: If I am remembering right, both mathematics and statistics were represented in the meeting at FAMU.

Kutzko: Yes, that is right. In fact, the Alliance has served all of the mathematical sciences from its very beginning. Dean Isaacson, who was chair of the Iowa State University statistics department, was a leader in the Alliance until his retirement. Kathryn Chaloner (Figure 1), chair of biostatistics at the University of Iowa until her untimely death, headed our Alliance statistics initiative. The biostatistics department provided the Alliance with office space and staff support until its move to Purdue. Leslie McClure, chair of biostatistics at Drexel University, has taken over Kathryn's responsibilities; she is our associate director for statistics.

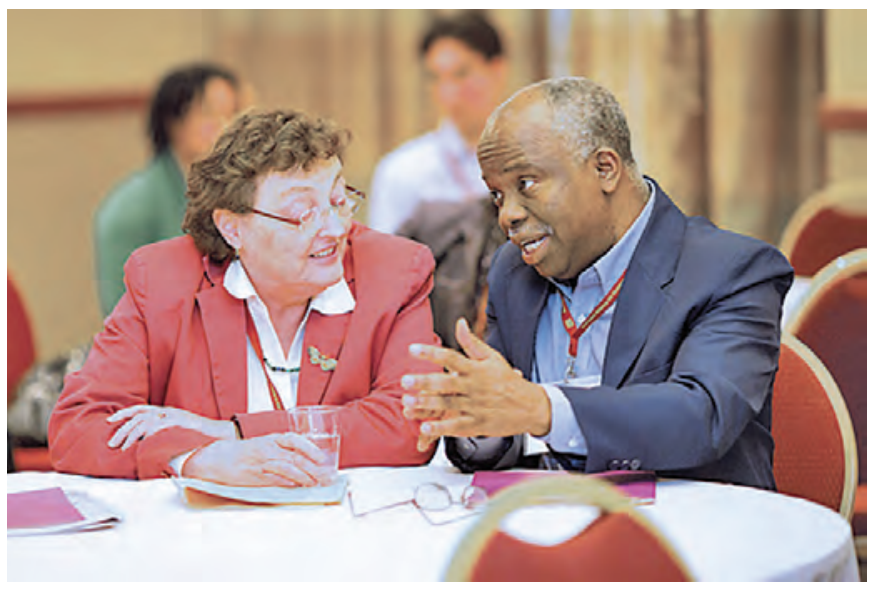

Figure 1. Kathyrn Chaloner, founder of the Alliance Statistics Initiative, talks with Professor Joe Omojola.

Goldberg: How did the new Alliance go?

Kutzko: We had mixed success. Quite a few students participated in the new Alliance each year, but not all of them had the background to enter our doctoral programs. Several of them entered the master's program at the University of Northern Iowa, but some of these students chose to enter doctoral programs in non-math sciences fields or they dropped out altogether. There were some real successes though, and one of them, Reggie McGee, received his $\mathrm{PhD}$ at Purdue.

Goldberg: Reggie was a really important figure in the transformation of our department, and we were very fortunate that he chose to come to Purdue. I first met Reggie when he was in the Alliance summer program at Iowa, and I happened to be there working with you on a research paper. Then a couple of years later he visited Purdue through the HBI Visitation Program, and we were 

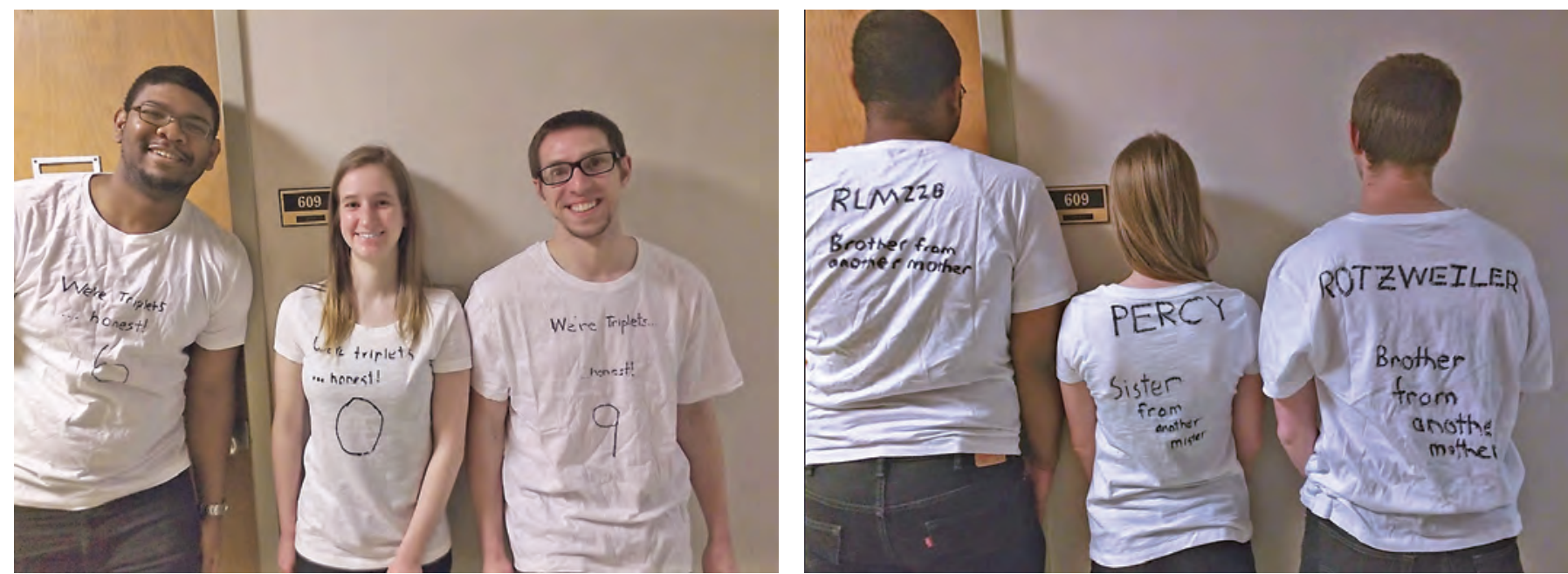

Figure 2. Reggie McGee started a grad student Twin Day and posed with his office mates Sarah Percival and Kevin Rotz as triplets.

successful in recruiting him to our department. If I remember right, you called me to say we should take him. He forged a community for himself within the department right away, and was quite a cheerleader for people succeeding and working together, for instance on preparing for qualifying exams. He also connected with the wider campus community, and he was very active in the Purdue Black Graduate Student Association. He also became a graduate representative in our department; he represented the grad students to the grad chair (me), and he had a lot of good ideas about making our department a better place. He and his fellow grad reps had a whole series of events and competitions for the week before final exams. One day was Twin Day, where you had to find someone and dress up as twins. Reggie and his office mates actually went as triplets (Figure 2), and it was pretty hilarious. He also was very outspoken about certain conditions for the graduate students. This helped set a tone for how dialog between the faculty and grad students about our climate could move forward.

Reggie worked with Greg Buzzard (now head of our department) on mathematical biology. With Greg, Reggie really blossomed as a researcher. His thesis studied something about modeling certain signal processes between diseased cells. He finished in six years, and then took a postdoc position at MBI.

Kutzko: You were fortunate in the make-up of your department during your transition from a more traditional department to one of our strongest Doctoral Program Groups (DPGs).

Goldberg: Yes. Rodrigo Bañuelos and Johnny Brown had already been in our department for a long time, and both have been stalwarts in working for diversity in our department and across campus. They have been great role models and mentors not only to minority students but also to majority students and junior faculty. At one point Rodrigo was head and Johnny was associate head, and one external review commented that to their knowledge it was the first time a Group I department had had underrepresented minority faculty in both of its top two leadership positions. We're also lucky that Greg Buzzard is now our head; he has been very proactive in diversity issues, and supportive of initiatives to improve the climate. $\mathrm{He}$ was a big part of making the idea that the Alliance could come to Purdue a reality. We had the challenging task of replacing Billie Townsend (Figure 3) as program manager and were lucky to hire Rebecca Lank. And, of course, neither the transition you asked about nor the Alliance's move to Purdue could have occurred without Edray Goins! Edray joined our faculty in 2004 and, besides making an immediate contribution to our research effort, went about doing a lot of important things which hadn't been done before, such as undergraduate research. In addition to his work at Purdue, he has taken on several national roles, including president of NAM. When the Alliance moved to Purdue, we were really fortunate that Edray agreed to be associate director. He provided new ideas, strengthened ties with the HBCU community, and played a crucial role

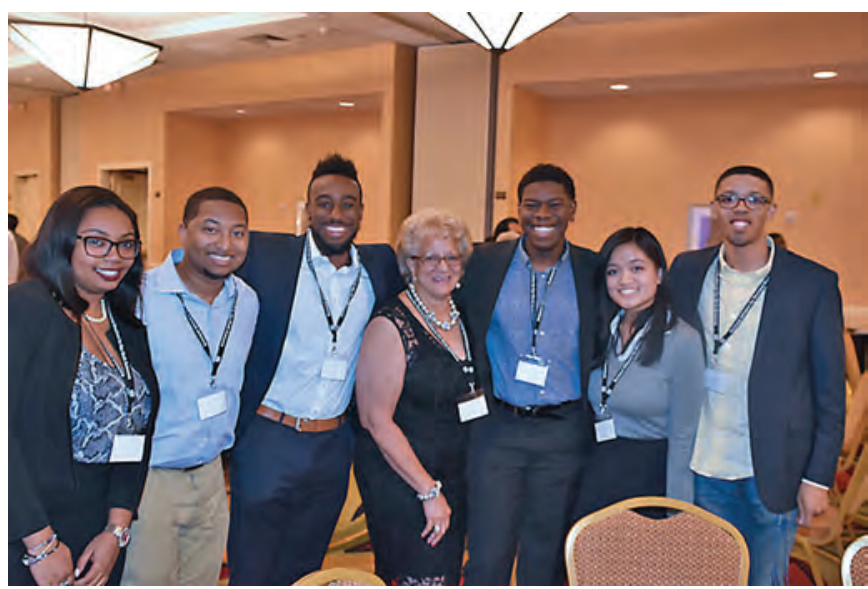

Figure 3. Billie Townsend (center), retired Alliance program manager, and some Alliance scholars at the 2016 Field of Dreams Conference. 
in all developments and decisions. Edray has decided to step away from his work with the Alliance, and he'll be joining the faculty at Pomona College in the fall of 2018.

Kutzko: The Alliance has come a long way from its origins as a partnership between four HBCUs and the three Iowa Regents Universities. As our new executive director, how does it look to you now?

Goldberg: The Alliance has changed in certain fundamental ways since 2007 , when the decision was made to transform the original partnership into a national community. And it changed again in 2016 when we evolved from an NSF-funded project to an independent organization, ${ }^{5}$ an organization with the potential to transform the culture and the demographics of our math sciences professions. But what will never change will be our commitment to the African American community.

- We have strong ties with NAM and look forward to working with them in the coming years.

- We have built a strong tie with CAARMS and with its director, Bill Massey, and will work closely with Bill and with the CAARMS network as we continue to build regional alliances in the Northeast.

- We have close relationships with the faculty of several HBCUs including, of course, our original partners Jackson St. and FAMU, but also Southern University at New Orleans, Xavier University of Louisiana, Morehouse College, Spelman College, and Texas Southern University. These and other HBCUs are enrolling an increasing number of their Alliance Scholars each year into our Facilitated Graduate Admissions Process (F-GAP) program and, with the help of F-GAP, more and more of these African American Alliance Scholars are entering graduate programs in the mathematical sciences. (See Figure 4.)

Our numbers so far are good. Over the last two years, twenty-one minority students who started out as Alliance Scholars earned a doctoral degree in a math science. Of these students, almost half (nine) were African Americans. And we have every reason for optimism when we look at our DPGs. In fact, over the past ten years, at least 80 African Americans have been awarded PhDs by these departments, about thirty-eight percent of all doctoral degrees awarded to African Americans in the math sciences during this time.

Kutzko: Our colleague, Leslie Hogben, over at Iowa State University has informed me that their math department will be awarding PhDs to four African American mathematicians in spring and summer, 2018, a fitting achievement for original Alliance. ${ }^{6}$ one of the founding departments of the

Goldberg: Any final thoughts?

Kutzko: I guess we both feel humbled by these accomplishments. I grew up at a time when schools were segregated and I can remember seeing the separate drinking fountains. I remember the deep sense of injustice my parents felt about this and how strongly they expressed it. And I remember your dad and mom and that they had devoted their lives to making the kind of change that we have had the honor to be a part of through the Alliance.

I never thought that, through this work, I would have the opportunity to meet some real heroes, like Bob Moses and our friend Donald Cole, who has played such a critical leadership role in our Alliance community. I never thought I would live to see Barack Obama become President of the United States, and I certainly never imagined that I would
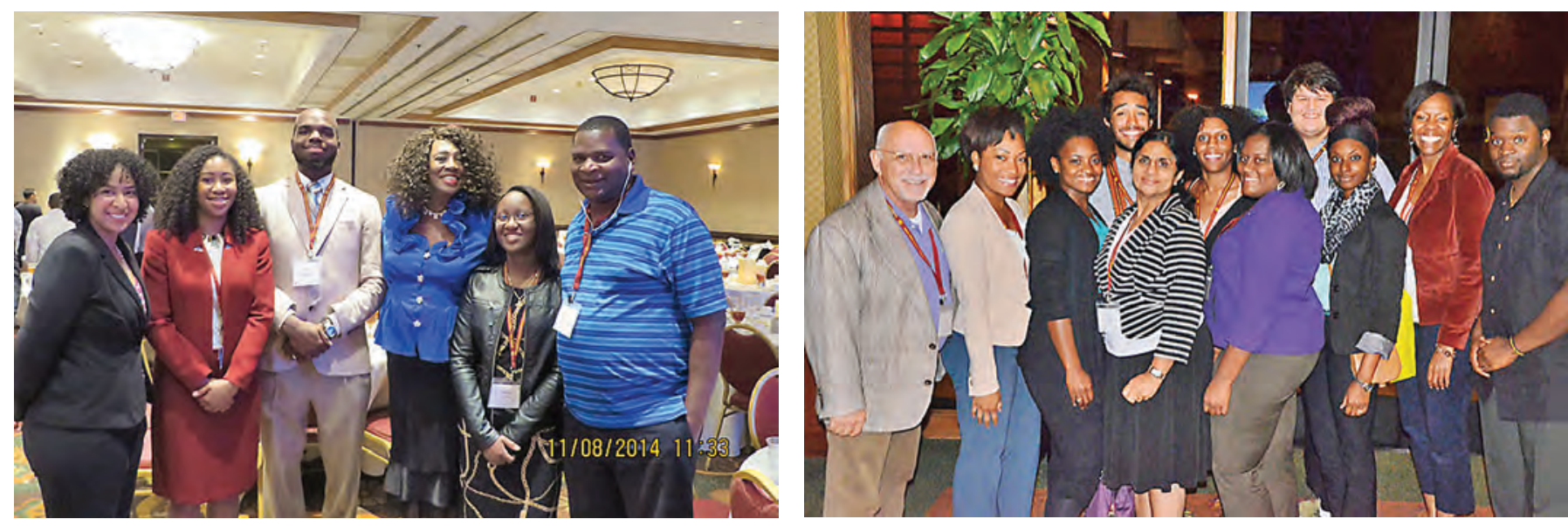

Figure 4. The Alliance has close relationships with several HBCUs. Left: Texas Southern students, alums, and faculty at the 2014 Field of Dreams Conference: Valerie Tolbert, Marquesha Forman, Aqeeb Sabree, Joan Evans, Franchell Davidson, Roderick Holmes. Right: Professors Lester Jones (left) and Sindhu Unnithan (center) and the Xavier University of Louisiana contingent at the 2014 Field of Dreams Conference.

\footnotetext{
${ }^{5}$ Information about the history and governance of the Alliance as well as complete data may be found at mathal1iance.org/ about-the-math-a11iance/.
}

${ }^{6}$ In 2015, the mathematics department at Iowa State won the AMS Award for an Exemplary Program or Achievement in a Mathematics Department; see www . ams . org/notices/201505/ rnoti-p544.pdf 


\section{BLACK HISTORY MONTH}

get a chance to meet him. But, most of all, I never imagined that there were so many faculty in our professions who felt just as you and I do, who remember how things were and who will give their time and their heart to making sure that our professions provide a welcoming and supportive environment to anyone who feels the unlikely passion that we feel for what everybody else sees as hopelessly abstract.

The Alliance has broken new ground, but there were big steps in this direction before. Among others, we should never forget Raymond Johnson, whose accomplishments at the University of Maryland taught us what might be possible at our Iowa schools and at Purdue. But, again and again, a shift of emphasis in a department or a change of administration at a university or even a couple of retirements have led to a loss of momentum and the process must be begun again. So I would like to end with a plea: This time, let's make it permanent! Let us work together to institutionalize what the Alliance has accomplished in our colleges, and universities, and professional organizations.

EDITOR'S NOTE. Also see the September 2016 Notices interview with Goldberg and the December 2017 AMS inclusion/exclusion blog post on the Math Alliance at http://bit.7y/2ABtLRI.

\section{Photo Credits}

Figure 1 by Matt Le.

Figure 2 by Rebecca Lank.

Figure 3 by Donald Cole.

Figure 4 by Billie Townsend.

Figure 5 by Donald Cole.

Photo of Phil Kutzko and David Goldberg by Donald Cole.

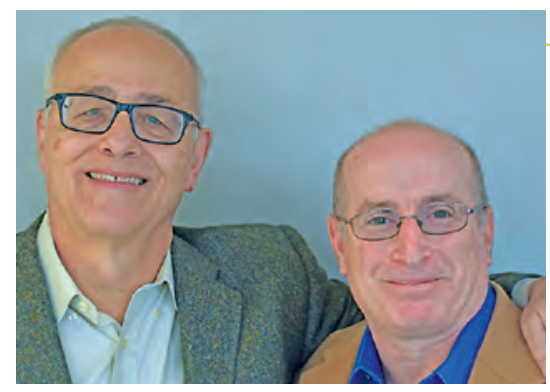

Phil Kutzko and David Goldberg
ABOUT THE

AUTHORS

Phil Kutzko and David Goldberg at the 2017 Field of Dreams Conference. Phil still dreams of beating David at handball, some day. 


\section{Behind Every Successful Woman, There Are a Few Good Men}

\section{Talitha M. Washington}

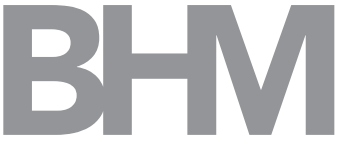

I am fortunate that throughout my mathematical journey, I have had a few good men give me the courage, persistence, and drive to persist in mathematics. I share my story in the hopes that those needing courage receive it and those who can offer help give it. Society may not be just, but each of us can add goodness in all that we do.

As an undergraduate I went to Spelman College, a Black woman's college in Atlanta, Georgia. College was a huge class shock for me, because I grew up in the inner city of Evansville, Indiana, where many of my friends ended up going to jail or prison. At Spelman, I was immediately blessed with not being the only Black female in the class. For the first time in my educational experience, I did not have to be the "negro representative" who is called upon to explain and defend Black people. I did not have to explain my race or why I look this way. Rather, I could simply learn and absorb copious amounts of knowledge centered around my perspective as a Black woman in a multicultural world.

As an undergraduate, I had zero aspirations of going to graduate school. I wanted to work in the business world because that is what I thought I knew. Then along came Jeffrey Ehme (Figure 1), who took me on as a student researcher and in my senior year forced me to apply to graduate school. Had he not made me apply, I would not be here today as a mathematician, and you would not be reading this article.

Life in graduate school at the University of Connecticut was hard. People always asked me what country I was from. That was confusing to me. I later found out that I

Talitha M. Washington is associate professor of mathematics at Howard University. Her email address is tal i tha.washington@ howard. edu. See a write-up of her talk at the 2017 SIAM annual meeting Hidden Figures event www. siam . org/meetings/an17/ figures.pdf.

For permission to reprint this article, please contact: reprint-permission@ams . org.

DOI: http://dx.doi.org/10.1090/noti1634

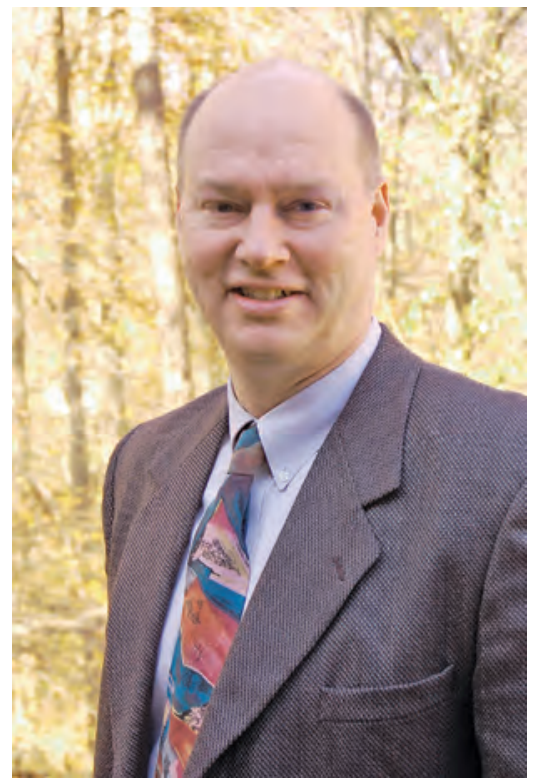

Figure 1. Jeffrey Ehme took me on as an undergraduate research student and forced me to apply to graduate school.

McKenna researched. I was more interested in mathematical biology; so I completed my dissertation under Yung-Sze Choi on a partial differential equations model of proteins acting as on/off switches. In 2001, I became the first African American to graduate with a doctorate in mathematics from the University of Connecticut.

Much of my professional career has been guided by Ronald E. Mickens of Clark Atlanta University ${ }^{1}$ (Figure 3). I knew him as an undergraduate because Clark Atlanta was literally right across the street from Spelman. I remember that when I was an undergraduate he gave me his book on difference equations, which tended to gather dust over the

${ }^{1}$ See Mickens's article on "Nonstandard Finite Difference Schemes" in the January 2018 Notices. 


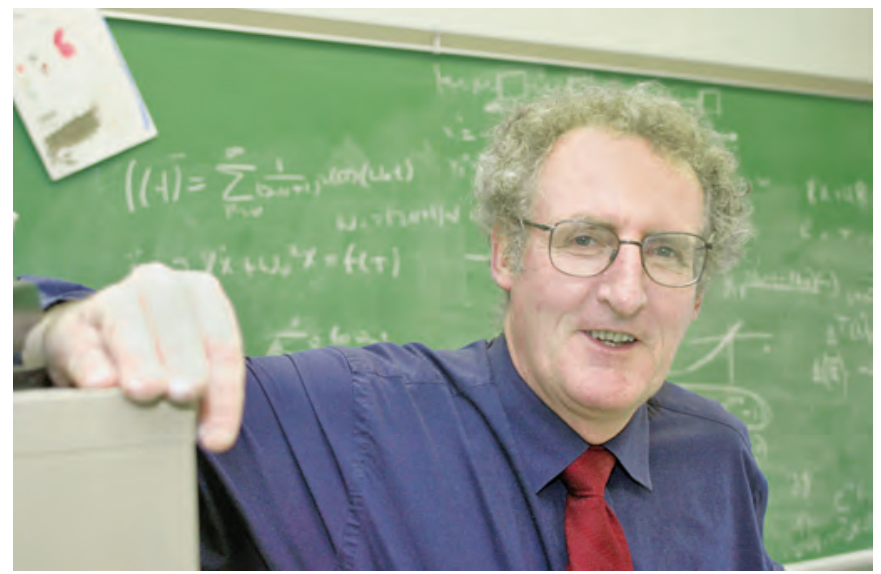

Figure 2. In graduate school at the University of Connecticut, Joe McKenna told me, "You outwork anyone here. You are good."

years. Little did I know that a decade later we would do research together. Over the years we have published papers on the construction of nonstandard finite difference schemes. These schemes discretize dynamical systems and maintain dynamical consistency by incorporating features of the dynamical systems into the discretizations. We now talk a couple of times a week about math, life, and what I should be doing and how I should do it. My graduate student at Howard University, Seye Adekanye, chose to work on the development of nonstandard finite difference schemes of the Tacoma Narrows Bridge for his dissertation. For me his work is a beautiful union of both McKenna and Mickens, two men who continue to inspire my mathematics.

At Howard our departmental meetings are held in a room with that grand picture of Elbert Frank Cox (Figure 4). In 1925 Cox became the first Black in the world to earn a doctorate in mathematics. I did not learn about Cox until I was grown, even though we grew up in the same neighborhood in Evansville, Indiana. Cox was hidden to me. He spent most of his professional career at Howard, as do I. When I sit in departmental meetings, I tend to space out and catch myself staring at his photo and he stares back, encouraging me to continue the pursuit of mathematics and justice.

I'm thinking back to Katherine Johnson, who was featured in the Hollywood movie Hidden Figures, surrounded by white males at NASA. Every time they asked her to do something, she outworked them and did more. She was able to do this because of her mathematical research training at West Virginia State University, a Historically Black University. When she entered West Virginia, so did her professor William Claytor, who is also a Howard graduate. She once asked Claytor, "If I got into math, will anyone hire me?" Claytor replied, "You'll have to see.... That is your problem." Claytor knew that she should pursue mathematics. After graduating, the president of her alma mater, John Davis, a Morehouse man, handpicked her to integrate West Virginia public schools in a graduate program, for he also knew she should pursue mathematics. She enrolled in a summer session, but her training in math was so good that no course could duplicate what she already knew from Claytor.

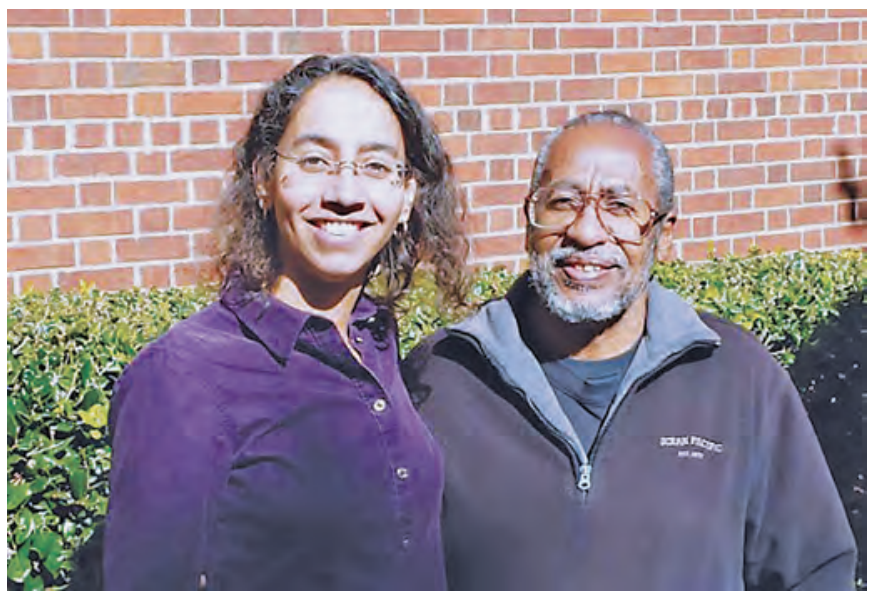

Figure 3. Much of my professional career has been guided by Ronald E. Mickens of Clark Atlanta University.

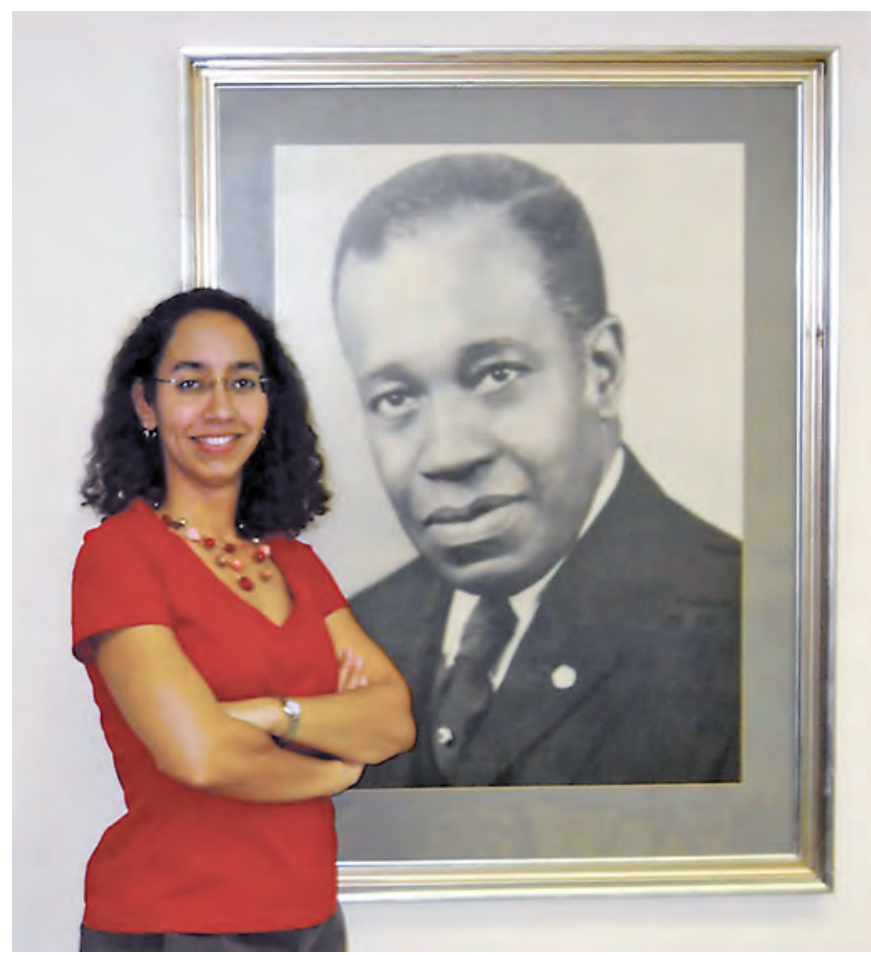

Figure 4. At Howard University, I stand by the grand photo of Elbert Frank Cox, the first Black in the world to earn a doctorate in mathematics. 


\section{BLACK HISTORY MONTH}

\section{so that our children \\ can see that they too can become mathematicians}

This past summer while driving to the SIAM meeting in Pittsburgh, Pennsylvania, I passed through West Virginia. I happened to glance over and see a road sign that read "West Virginia State University." Sitting right beside me was my teenage daughter, snoring away, wearing her Hidden Figures T-shirt. As a mathematician, mother, and activist, I hope that we all remain unhidden so that our children can see that they too can become mathematicians. I am deeply thankful for those few good men who helped me along my way so that I could become an unhidden research mathematician.

\section{Photo Credits}

Figure 1 by Maria Ehme.

Figure 2 courtesy of the University of Connecticut.

Figures 3 and 4 courtesy of Talitha Washington.

Author photo @Lifetouch Portrait Studios, Inc.

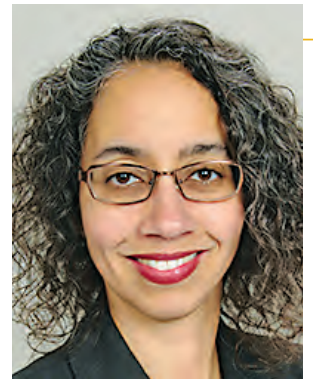

Talitha M. Washington

\section{ABOUT THE AUTHOR}

Talitha M. Washington is interested in applications of differential equations to problems in biology and engineering, as well as the development of nonstandard finite difference schemes to numerically solve dynamical systems. Her three teenagers are STEM bound. In her spare time, she enjoys kickboxing, weight- lifting, aerobics, running, and yoga. 


\title{
Episodes in the Life of a Genius: J, Ernest Wilkins Jr.
}

\author{
Asamoah Nkwanta and Janet E. Barber
}

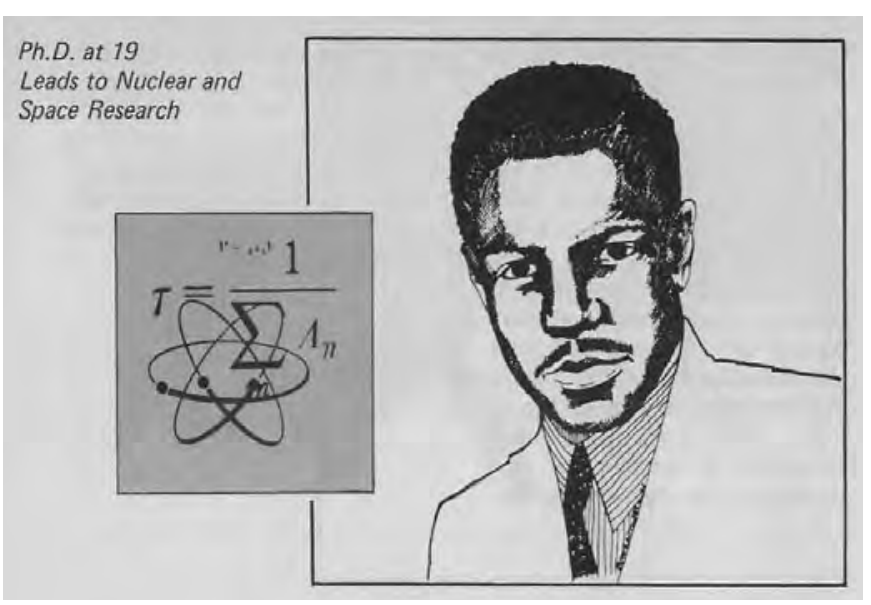

ABSTRACT. J. Ernest Wilkins Jr. had an IQ of 163 by age nine, earned a college degree at age sixteen, and received his doctorate in mathematics at age nineteen from the University of Chicago. This paper highlights his noteworthy contributions as a mathematician, physicist, engineer, and educator.
Asamoah Nkwanta is chair of the Department of Mathematics at Morgan State University. His email address is asamoah. nkwanta@morgan. edu. Janet E. Barber is chair of the School of Arts and Sciences at Stratford University, Alexandria, Virginia. Her email addresses are jbarber774@gmai 1. com and jabarber@ stratford. edu.

For permission to reprint this article, please contact:

reprint-permission@ams.org.

DOI: http://dx.doi.org/10.1090/noti1636

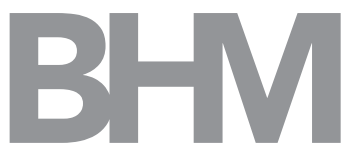

\section{Introduction}

By the age of nineteen, J. Ernest Wilkins Jr. had earned a doctorate in mathematics from the University of Chicago. Before being conferred with his $\mathrm{PhD}$, young Wilkins applied to the Institute for Advanced Study (IAS) in Princeton and was invited to become a member shortly thereafter. Over his career, this child prodigy and scientist made notable contributions to mathematics, physics, engineering, and education.

\section{Child Prodigy with a Big Bang IQ}

"One day, I'll fly to the moon with math." —Wilkins

In the 1930s Martin D. Jenkins [3], an educational psychologist (and president of Morgan State College, 1948-1970), conducted a study on highly intelligent African American children. Wilkins was classified a genius at age ten with an IQ of 163, surpassing the genius level of 150. Wilkins modestly informed Nkwanta that he was surely case no. 2 (see Table 1 ) and that he always wondered what happened to case no. 1, the young African American female genius with the IQ of 200.

Jenkins [3, p. 165] wrote:

Finally, these cases bring into sharp focus the limitations which our society places on the development of the highly gifted Negro. These children are nurtured in a culture in which racial inferiority of the Negro is a basic assumption. Consequently, they will experience throughout their lives, educational, social and occupational restrictions which inevitably affect achievement and motivation. ... Some of these individuals will meet frustration and draw away; others will go on to careers of high usefulness and accomplishment.

Though Wilkins was brilliant to genius level and many of his colleagues and mentors wrote letters of recommendation after his tenure with the Institute for Advanced 


\begin{tabular}{|c|c|c|c|c|c|c|}
\hline Case no. & Location & Age & S. Binet IQ & EQ (educ) & Grade & Race \\
\hline $\begin{array}{l}1 \text { Unknown } \\
\text { African American (F) }\end{array}$ & Chicago & $9-5$ & 200 & 158 & $5^{\text {th }}$ & $N$ \\
\hline 2 J. Ernest Wilkins, Jr. (M) & Chicago & $10-6$ & 163 & 169 & $8^{\text {th }}$ & NWW \\
\hline $\begin{array}{l}3 \text { Unknown } \\
\text { African American (M) }\end{array}$ & Cincinnati & $6-9$ & 173 & 158 & $6^{\text {th }}$ & $\mathrm{N}$ \\
\hline $\begin{array}{l}4 \text { Unknown } \\
\text { African American (M) }\end{array}$ & Washington & $8-5$ & 163 & 169 & $6^{\text {th }}$ & NNW \\
\hline
\end{tabular}

Table 1. Wilkins's genius IQ of 163 appears in this edited chart entitled "Characteristics of 16 Negro Children of Binet IQ 150 and Above" from Martin D. Jenkins [3]. Under "Race," N denotes Negro, NWW denotes Negro with the possibility of white ancestry, and NNW denotes more Negro ancestry than white ancestry.

Study, research universities were unwilling to employ an African American. Therefore, most of Wilkins's active scientific career was with industry, the government, and academics working with Historically Black Colleges and Universities (HBCUs), such as Tuskegee, Howard, and Clark Atlanta.

As noted, Wilkins did experience his unfair share of racism and discrimination; however, he persevered. At age twenty, he worked on national projects, training and teaching pre-flight mathematics to hundreds of Tuskegee Airmen in the Army Air Force College Training Program. Between 1941 and 1945 Tuskegee Institute trained over 1,000 African American aviators for the war effort. As his career progressed, he received numerous honors for his work.

\section{Early Life of a Genius}

Wilkins's mother, Lucille B. Wilkins, was an educator who studied mathematics, and his father, J. Ernest Wilkins Sr., was an accomplished attorney, who graduated Phi Beta Kappa with a bachelor's degree in mathematics from the University of Illinois. Wilkins Sr. would eventually work for the White House during the Eisenhower administration. He was the first African American to participate in White House cabinet meetings. He served as assistant secretary of labor in 1954 and as a member of the Civil Rights Commission in 1958.

Wilkins Jr. was a child prodigy. At only a year old, he was able to recite the alphabet, and by the age of five he was able to add, subtract, multiply, and divide. He began school at the age of four. Coached at home by educated parents, Wilkins and his brothers were challenged with intellectual puzzles and math games. A high school teacher who recognized his talents and encouraged his mathematical genius enabled him to graduate from Parker High School in three years at age thirteen.

Wilkins gained fame upon entering the University of Chicago at age thirteen and becoming its youngest student. He participated in the William Lowell Putnam Mathematics Competition. He graduated Phi Beta Kappa at age sixteen in 1940. He completed his doctoral degree at age nineteen in 1942 with a dissertation titled "Multiple Integral Problems in Parametric Form in the Calculus of Variations," published in Annals of Mathematics (1944).

Prior to graduation, Wilkins penned a letter to the mathematician Oswald Veblen of the Institute for Advanced Study in Princeton, requesting permission to enroll there. Wilkins's Chicago dissertation advisor, Magnus Hestenes, followed up with a letter of support. In the letter, though he makes sure to inform Veblen that Wilkins is a good fellow and looks white, Hestenes also writes that "Mr. Wilkins is undoubtedly one of the best, if not the best, student [sic] we have had for a number of years." Wilkins received an offer and attended for three months, between 1942 and 1943. In a reply to Hestenes, Veblen indicated that Wilkins would be the second person of color to attend the Institute: "This year we have had another very good mathematician who came from the University of Illinois." The first African American member of the IAS was David H. Blackwell, who is the seventh African American to earn a PhD in mathematics, Wilkins the eighth. Veblen suggested that Wilkins write Blackwell to get suggestions for living arrangements in the Princeton area. Blackwell and Wilkins were contemporaries and attended many of the same mathematical conferences, meetings, and events in their future careers (see Figure 1).

While at the IAS, Wilkins was potentially exposed to the courses, works, and lectures of many internationally recognized mathematicians and physicists, such as Marston Morse, Hermann Weyl, Kurt Gödel, Wolfgang Pauli, Carl Ludwig Siegel, and Albert Einstein. Wilkins and Einstein were housed in the same office building. Wilkins wrote a letter, dated April 13, 1943, to Weyl indicating that he had taken courses in meromorphic functions by Weyl and algebraic geometry by Claude Chevalley. Wilkins wrote that he attended Solomon Lefschetz's seminar on non-linear differential equations and presented a report on a paper, 


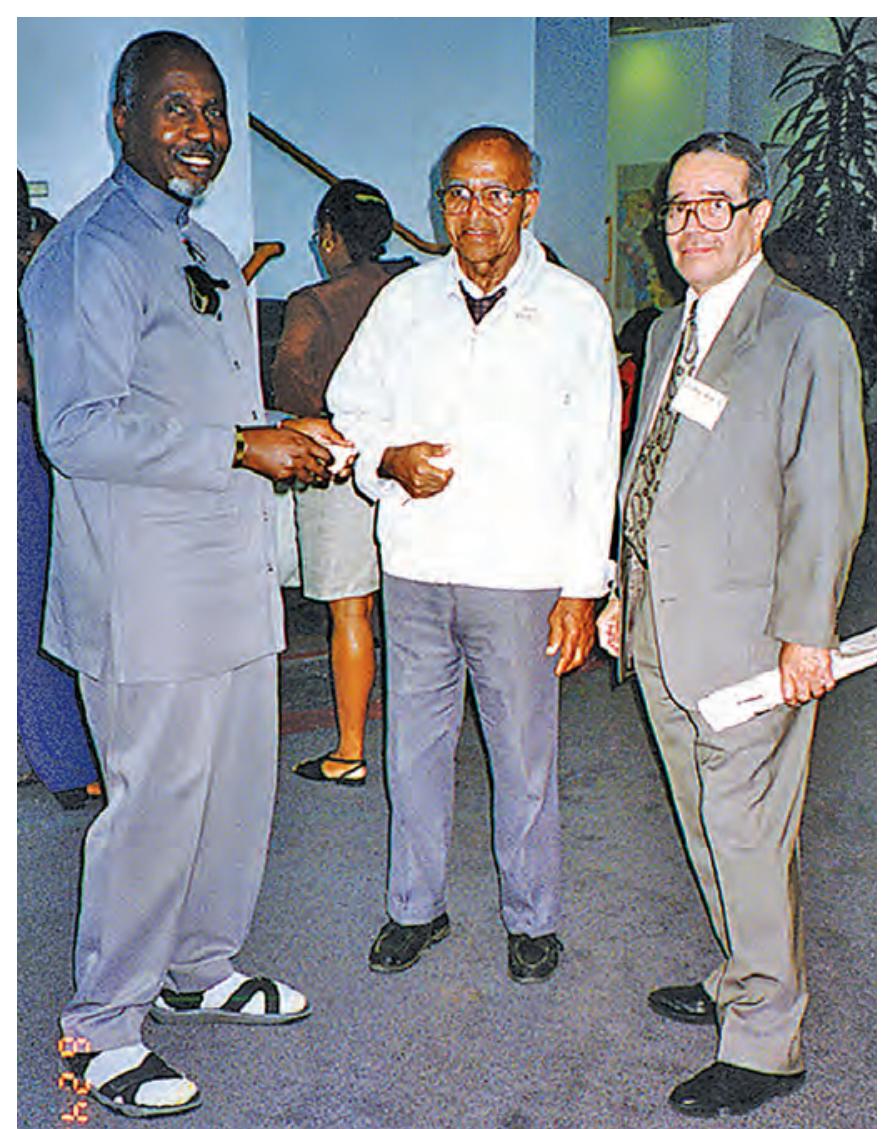

Figure 1. Abdulalim A. Shabazz, David H. Blackwell (the first African American member of the IAS), and Wilkins (the second), at the first CAARMS conference at MSRI in 1995.

"A General Equation for Relaxation Oscillations" by Norman Levison and Oliver K. Smith.

Wilkins later apparently requested a recommendation letter from one of his mathematics professors from Princeton University, IAS affiliate professor Lefschetz, when he was seeking an opportunity with the Navy Department. Lefschetz's letter, dated November 1, 1943, states that he had "formed the highest opinion of his capacity as a mathematician. He is exceptionally alert and hard working and I am certain would give you entire satisfaction in every way. I strongly recommend him."

Earlier 1943 letters disclosed that there was back-andforth correspondence between Wilkins and Morse. In one letter, Morse responded to Wilkins about information on local draft board forms and his position at Tuskegee Institute, as well as about work and education.

\section{The Teaching and Working Life of the Genius: Achievements, Honors, and Scientific Service}

Wilkins was a mathematics instructor at the Tuskegee Institute from 1943 to 1944, with work overlapping with industry. In 1944 he returned to the University of Chicago as associate mathematical physicist and as a physicist in its Metallurgical Laboratory, as part of the Manhattan Project, and discovered the Wilkins effect. He collaborated with the Nobel Prize-winning physicist Eugene Wigner on the Wigner-Wilkins Spectra, estimating the distribution of neutron energies within nuclear reactors.

Starting in 1950, Wilkins worked as a mathematician for the Nuclear Development Corporation of America. In 1956 he was elected Fellow of the American Association for the Advancement of Science and in 1964 Fellow of the American Nuclear Society. He was a visiting lecturer of the Mathematical Association of America from 1963 to 1967. During his remarkable career, Wilkins published many research papers and contributed to and solved many $M A A$ Monthly problems.

In 1970 Wilkins was invited by Warren Henry, a Tuskegee Institute and University of Chicago colleague, now a physics professor at Howard University, to come as a distinguished professor of applied mathematical physics. Wilkins accepted, helped establish the doctoral degree program in mathematics, and supervised four doctoral dissertations in physics.

Wilkins was president of the American Nuclear Society from 1974 to 1975 . Wilkins became the second African American to be elected to the National Academy of Engineering in 1976.

Wilkins was awarded an achievement medal in 1980 from the US Army for outstanding civilian services, the Quality Engineering for Minorities science award in 1994, and the National Association of Mathematicians (NAM) Lifetime Achievement Award also in 1994. The NAM inscription states:

In recognition of more than fifty professional years as a world class mathematician, physicist and engineer, gifted teacher and productive scholar it is NAM's distinct pleasure to name in your honor,

\section{THE J. ERNEST WILKINS JR. LECTURE}

To be given annually at the NAM undergraduate MATHFest conference and "Real Zeros of Random Polynomials," to be the inaugural J. Ernest Wilkins Jr. lecture.

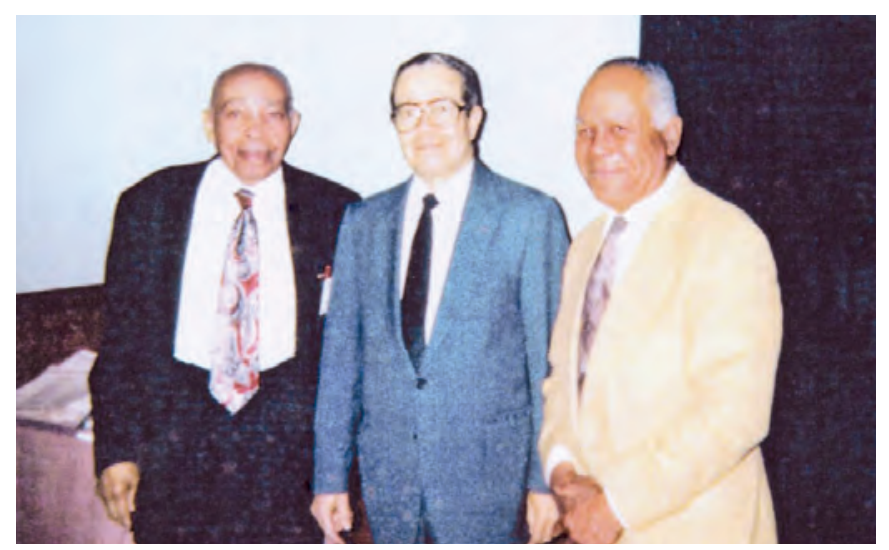

Figure 2. Warren E. Henry, Wilkins, and Henry McBay at the 1996 American Association for the Advancement of Science Meeting, Atlanta, GA. 


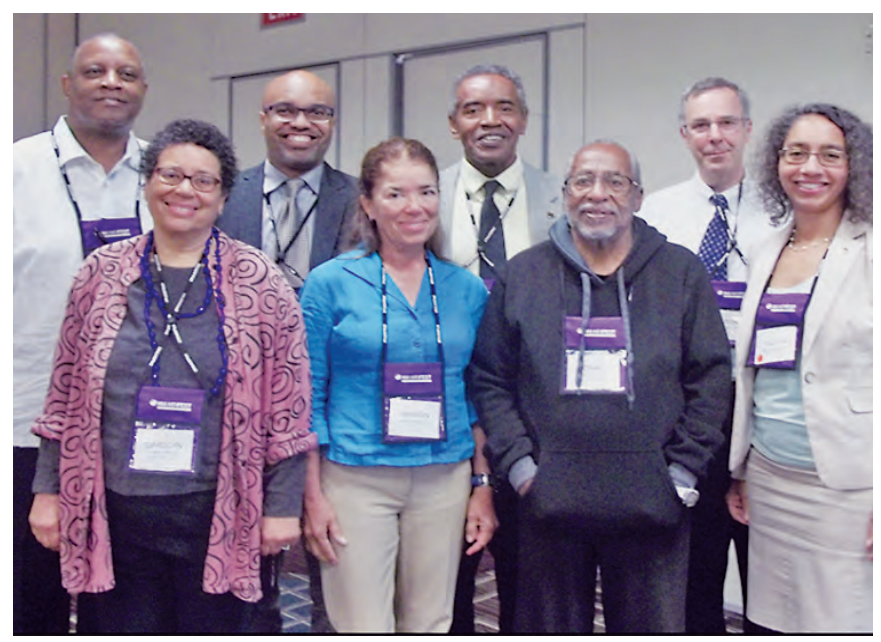

Figure 3. At "The Life and Legacy of J. Ernest Wilkins (1923-2011)," 2017 MathFest. Front row: niece Carolyn M. Wilkins, daughter Sharon Wilkins Hill, organizers Ronald E. Mickens and Talitha Washington. Back row: Nkwanta, organizer Ron Buckmire, former PhD student Cleo Bentley, Robert Fefferman.

Figure 2 shows Wilkins with two other icons in STEM, who were friends and contemporaries: Warren Henry and Henry McBay.

In 1996, Wilkins received the special recognition award from the US Department of Energy. A year later in 1997, he received a Professional Achievement Citation from the University of Chicago Alumni Association. In 2007 he was honored yet again at the University of Chicago in a special ceremony dedicating his portrait and plaque for display in the Eckhart Hall Tea Room.

The 2017 MAA MathFest held a special session on "The Life and Legacy of J. Ernest Wilkins (1923-2011)" (Figure 3). This session shared his impact in nuclear-reactor physics and optics, his plight of being a genius of color, and his admirable influence on the mathematical community.

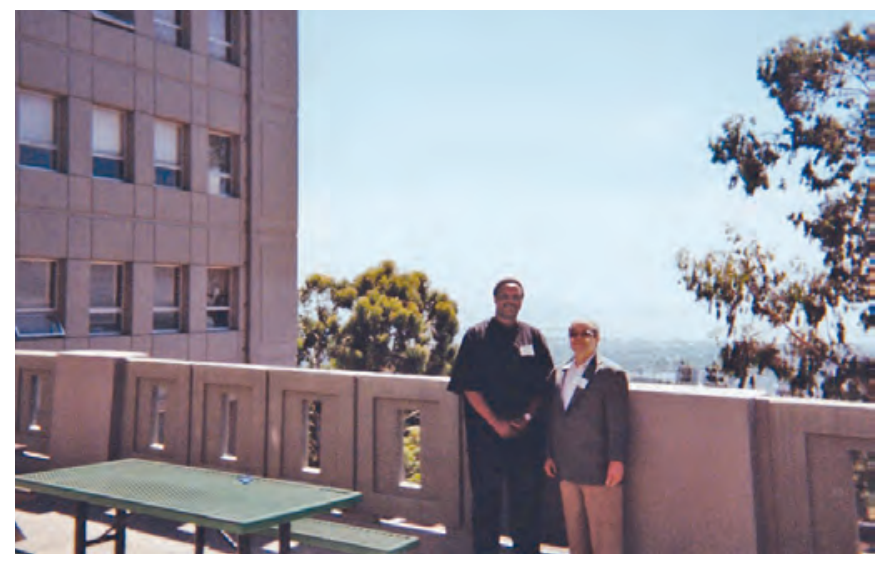

Figure 4. Wilkins with Nkwanta at CAARMS 10 at Lawrence Berkeley National Lab, California, 2004.

\section{References}

[1] N. Agwu, A. NkwAnTA, DR. J. ERnEST Wilkins, JR.: The Man and His Works, DIMACS Series in Discrete Mathematics and Theoretical Computer Science, Amer. Math. Soc. 34 (1997), 194-205.

[2] Institute for Advanced Study (IAS). The Shelby White and Leon Levy Archives Center, Princeton, NJ. Director's Office Member Files for: J. Ernest Wilkins Jr.

[3] M. JENKINS, Case Studies of Negro Children of Binet IQ 160 and Above, The Journal of Negro Education 12 (1943), 159-166.

[4] A. NKWANTA AND J. BARBER, African American Mathematicians and the Mathematical Association of America, MAA Centennial, Historical Articles (July 2015), https://www . maa.org/sites/defau1t/files/pdf/centennial/African_Americans.pdf

[5] C. M. WILKINS, Damn Near White: An African American Family's Rise from Slavery to Bittersweet Success, University of Missouri Press, Columbia and London (2010).

\section{Photo Credits}

Illustration of J. Ernest Wilkins is in the public domain.

Figure 1 courtesy of Raymond L. Johnson.

Figure 2 courtesy of Ronald E. Mickens.

Figure 3 courtesy of Cleo Bentley.

Figure 4 courtesy of Asamoah Nkwanta.

Photo of Asamoah Nkwanta courtesy of Charlita Woodruff-White. Photo of Janet E. Barber courtesy of Janet Barber.

\section{ABOUT THE AUTHORS}

Asamoah Nkwanta encountered Wilkins while an undergraduate at North Carolina Central University in the book Black Mathematicians and Their Works, while a graduate student at Howard University at the Institute on the History of Mathematics and its Use in Teaching workshop, and as a professor and research mathematician at several CAARMS conferences.

Janet E. Barber is a behavioral scientist, sociologist, editor, and writer, who collaborates and works with Nkwanta. Their many research collaborations began at North Carolina Central and Morgan State Universities. Her research and writing involve the study of positive psychology, critical thinking, cultural diversity, and leadership.

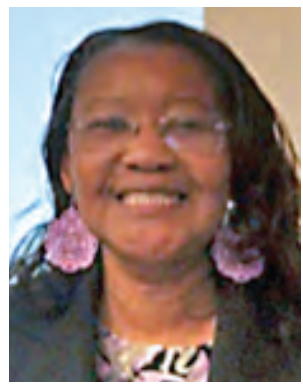

Janet E. Barber

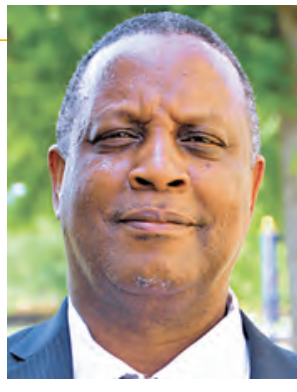

Asamoah Nkwanta 


\title{
Ten African American Pioneers and Mathematicians Who Inspired Me
}

\author{
by Johnny L. Houston
}

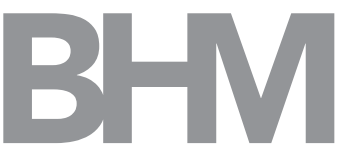

This article presents snapshots of the lives of ten African American pioneers and mathematicians who have inspired me in research, teaching, and life. The first five were amazing pioneers, and the second five were extraordinary researchers. At the end of the article are the names of five great African American mathematics teachers. In college I first learned of two of the teachers. In graduate school I learned of a few others. As my career developed, I learned of all of these persons and many more. They inspired me to be the best that I could be in the mathematical sciences community and

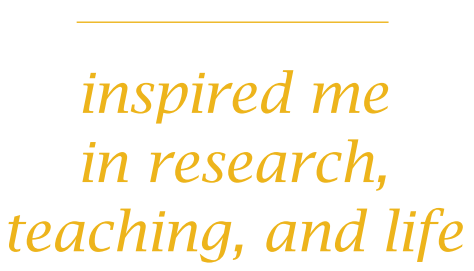
on the world scene. As a child I lived in abject poverty in governmental project housing in a one-parent family (a mother with no high school education). I was the only one of her four children to finish college. I earned three degrees in mathematics: A BA from Morehouse College, a MS from Clark Atlanta University, and a PhD from Purdue University. When I entered college I had never traveled outside the state of Georgia. By age 60, I had been to all 50 states and 60 countries on six continents and had produced over twenty publications. I want to share with young mathematicians the inspiration from earlier workers that enriched my life.

\section{BENJAMIN BANNEKER (1731-1806) Self-educated}

Benjamin Banneker was born a free Black man and was raised on a farm near Baltimore, MD. Although he period-

Johnny L. Houston is Executive Secretary Emeritus (1975-2000) of the National Association of Mathematicians. His email address is j1houston602@gmai1.com.

For permission to reprint this article, please contact: reprint-permission@ams . org.

DOI: http://dx.doi.org/10.1090/noti1639 ically attended a oneroom Quaker schoolhouse, Banneker was largely self-educated and did much of his learning through the voracious reading of borrowed books. He created puzzles for trigonometry that demonstrated his knowledge of logarithms. Banneker also attempted to find the exact lengths of an equilateral triangle inscribed within a circle where the diameter of the circle is known. While still a young man, he built a wooden clock that kept precise time until his death. As

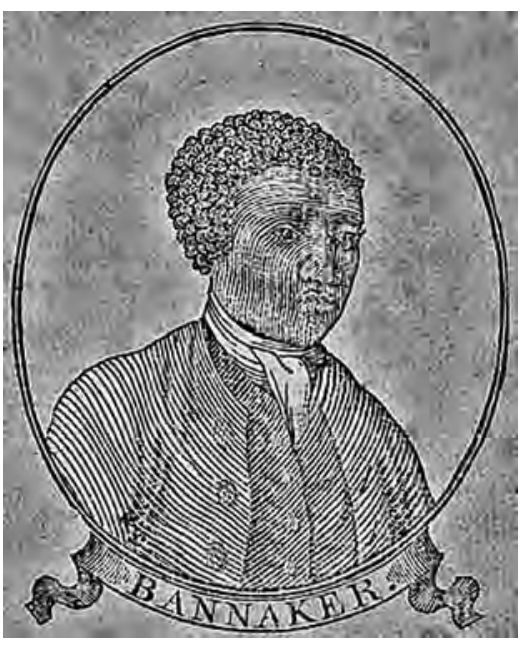

Benjamin Banneker: astronomer, mathematician, inventor, surveyor, publisher of almanacs, and author; one of the first recognized multi-talented African American intellectuals in the United States, often considered the first African American mathematician. early as 1788 , Banneker began to make astronomical calculations, and he accurately predicted a solar eclipse that occurred in 1789 . In 1791, Banneker helped survey the land that would become Washington, DC. Although a fire at his house on the day of Banneker's funeral destroyed many of his papers and belongings, one of his journals and several of his artifacts were saved and are presently available for public viewing. Many parks, schools, streets, and other entities have been named in his honor after his death. In recent years, a US postage stamp was printed in his honor. Currently the Benjamin Banneker Association, of which I was a member, promotes mathematical development at the high school level. 


\section{EDWARD}

ALEXANDER

BOUCHET (1852-

1918) Yale U. BS

1874, PhD 1876

Edward Alexander Bouchet was an American physicist and educator. He received a $\mathrm{PhD}$ from Yale in 1876 , the first by an African American from any American university. Bouchet was unable to find a university teaching position after receiving his $\mathrm{PhD}$ because of his race. He moved to Philadelphia in 1876 and took a position at Philadelphia's Institute for Colored Youth (now Cheyney

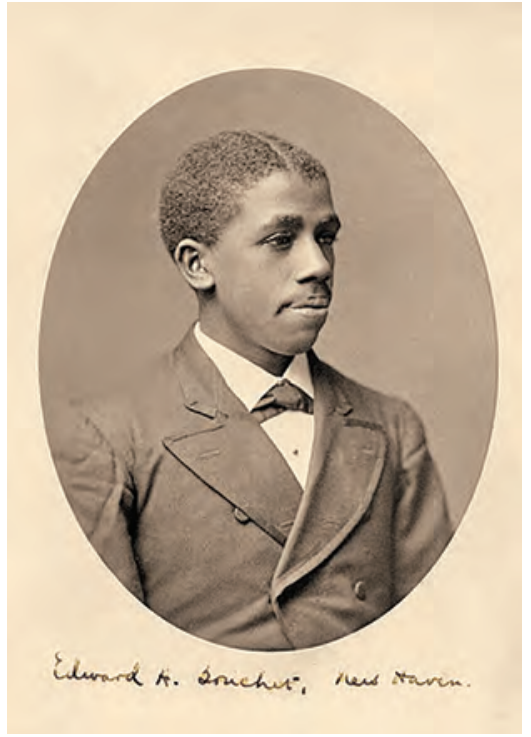

Edward Alexander Bouchet: The first African American to earn a PhD degree from an American university.
University of Pennsylvania), where he taught science and mathematics for the next twenty-six years. He resigned in 1902, spending the next fourteen years in a variety of jobs. In 1916, illness forced him to move back to his childhood home (New Haven, Connecticut), where he died in 1918. Currently, the American Physical Society confers the Edward A. Bouchet Award on some of the nation's outstanding physicists. Yale University and Howard University founded the Edward A. Bouchet Graduate Honor Society in his name. Yale also gives a Bouchet Leadership Award to help advance diversity in higher education. In 1988 the Edward Bouchet Abdus Salam Institute (EBASI) was created by Abdus Salam, a Nobel Laureate, in Trieste, Italy. One objective of EBASI is to provide for synergistic scientific and technical collaborations between African and American physical scientists. I presented at two EBASI conferences in Africa.

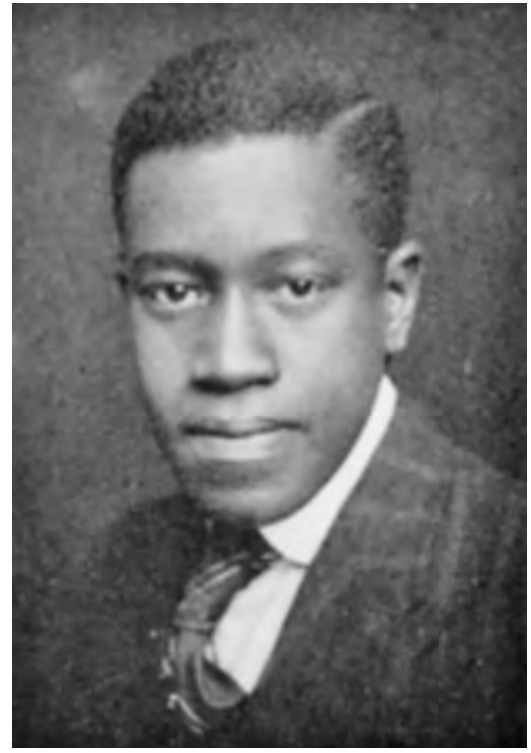

Elbert Frank Cox: The first Black person to receive a $\mathrm{PhD}$ in mathematics. Germany refused to accept Cox's dissertation (probably because of race), but Japan's Imperial University of San Dei accepted it. Cox inspired many future Black mathematicians and served a 40-year-long teaching career at Howard University and West Virginia State College. The National Association of Mathematicians Cox-Talbot Address is delivered annually at the Joint Mathematics Meetings in his honor, and the Elbert F. Cox Scholarship Fund at Howard University is used to help Black students achieve higher educational goals.

\section{WALTER \\ RICHARD TALBOT (1907-1977) U. of Pittsburgh BS 1931, MA 1933, PhD 1934}

Walter Richard Talbot accepted an assistant professorship in mathematics in 1934 at Lincoln University in Missouri, moving through the ranks to full professor while also serving as department chair (1940-1963), dean of men (1939-1944), registrar (1946-48), and acting dean of instruction (1955-

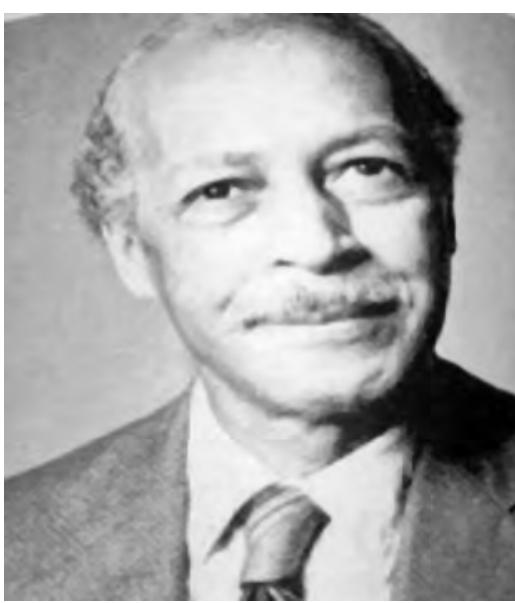

Walter Richard Talbot: fourth African American to receive a PhD in math, a founder of the National Association of Mathematicians.
1957). In 1963 Talbot accepted the positions of professor and department chair of mathematics at Morgan State University, remaining there until he retired in 1977. Talbot 
served the MAA in several significant capacities, and he was a major driving force among the seventeen who came together in January 1969 to found the National Association of Mathematicians (NAM). More than any other single individual, it was Talbot's leadership, guidance, organizational skills, and networking skills that raised funds for the establishment of NAM. In 1978, at a luncheon "In Memorial," Morgan State University named a scholarship in his honor. In 1980, NAM honored Talbot with the inauguration of the annual Cox-Talbot Address.

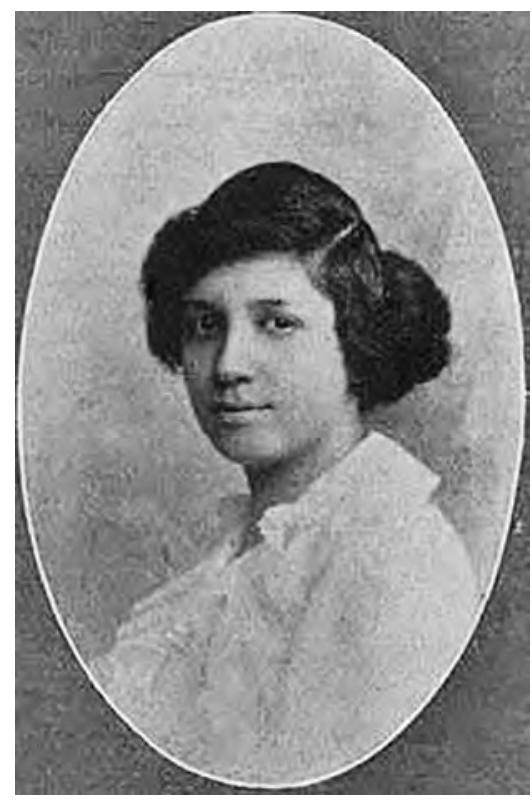

Euphemia L. Haynes: The first African American woman to earn a PhD in mathematics.

EUPHEMIA L. HAYNES ${ }^{2}$ (18901980) Smith C. BA 1914, U. Chicago MA 1930, Catholic U. PhD 1943

Martha Euphemia Loften Haynes was the first Black American woman to earn a $\mathrm{PhD}$ in mathematics. Haynes spent all of her professional life in Washington, DC. She was the first woman to chair the DC School Board. Haynes also served as math chair at Dunbar High School and at DC's Teachers College. At Miner Teachers College she established the math department, and at Howard University she taught part-time as an adjunct professor. She was a prominent figure in bringing about integration in the DC public school system and in the Archdiocesan Council of Catholic Women. Haynes received many awards, including election as Fellow in the American Association for the Advancement of Science in 1962. NAM honored her and two other Black women mathematicians by establishing the Haynes-Granville-Brown Colloquium Lecture Series that is given annually at NAM's national meeting at the JMM. Her highest awards resulted from her humanitarianism and generosity. Upon her death, US\$700,000 was bequeathed to Catholic University in a trust for a chair and student loan fund in her name.

\section{DUDLEY WELDON WOODARD (1881-1965) Wilberforce U AB 1903, U. Chicago BS 1906, MS 1906, U. Penn PhD 1928}

Dudley Weldon Woodard managed to get his master's thesis and other research papers published in repu-

\footnotetext{
${ }^{2}$ See the article on Haynes in the October 2017 Notices www . ams. org/publications/journals/notices/201709/rnoti-p995. pdf.
}

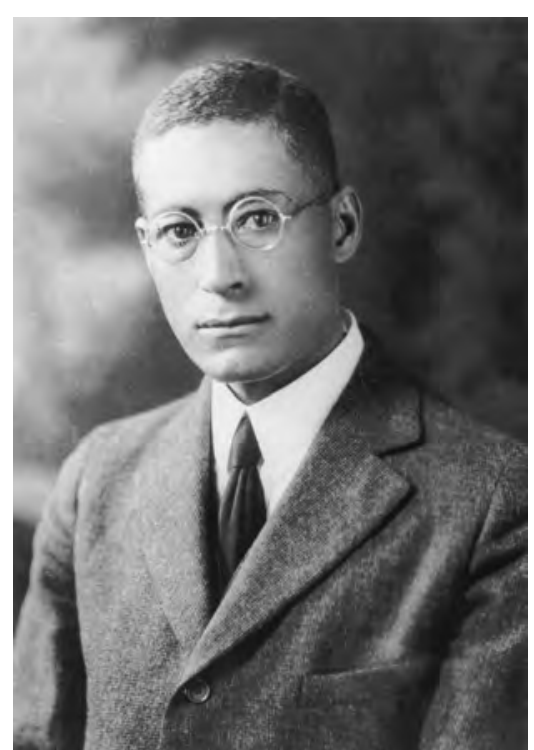

Dudley Weldon Woodard: The second African American to earn a PhD in mathematics, established the mathematics MS degree program at Howard University in 1929. cluding recruiting Elbert Cox. Woodard devoted his entire professional life to the promotion of excellence in mathematics through the advancement of his students, in teaching, and in research. Woodard's students who also earned the $\mathrm{PhD}$ degree in mathematics included $\mathrm{W}$. W. S. Claytor, George Butcher, Majorie Lee Brown, and Eleanor Jones. NAM honored Woodard with the naming of the Claytor-Woodard Lecture, given annually at NAM's national meeting at the Joint Mathematics Meetings.

\section{WILLIAM W. \\ CLAYTOR (1908- \\ 1967) Howard U. \\ BS 1929, MS 1930, \\ U. Penn. PhD 1933}

William Waldron Schieffelin Claytor was Dudley Woodard's most promising student at Howard. Thus it was not surprising that William Claytor was recommended for further studies at the University of Pennsylvania. Claytor quickly earned himself an outstanding reputation at U. Penn., where he won the Harrison Fellowship in Mathematics-the

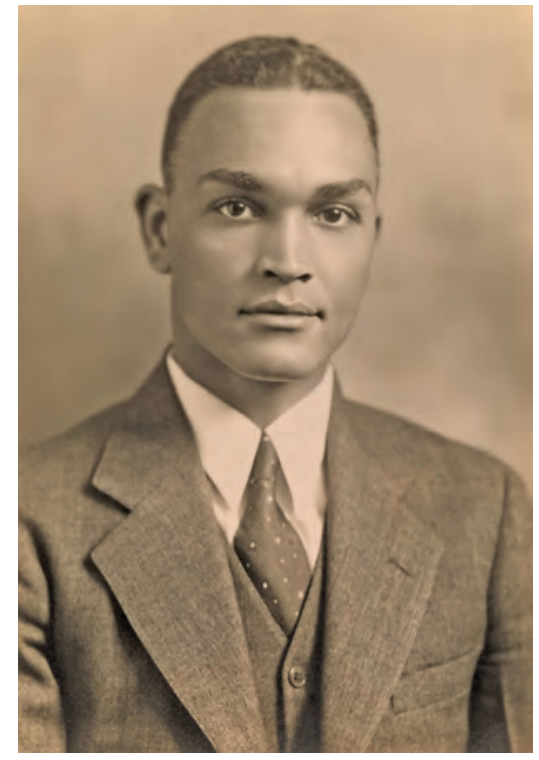

William W. Claytor: The third African American to earn a $\mathrm{PhD}$ in mathematics and a distinguished topologist. 
most prestigious award U. Penn offers. His dissertation under J. R. Kline was also well received by the faculty. After the completion of his PhD, Claytor accepted a teaching position at West Virginia State College, where he remained for three years. In 1937 he was awarded a Rosenwald Fellowship and pursued postdoctoral studies at the University of Michigan, where R. L. Wilder had attracted an able and experienced group of topologists. Kline had written Wilder about Claytor's abilities, and they both were pleased that Claytor was able to join the group at Michigan, which included S. Eilenberg, W. L. Ayers, E. W. Miller, and S. B. Myers. Claytor's published mathematical work, on imbeddability and Peano continua, attracted considerable attention throughout the topological community and still does today. At the end of his postdoctoral studies at Michigan, Claytor was recommended by his colleagues in topology for a faculty position at Michigan. The administration took a firm stand that no such appointment would be made, as did other major research institutions. After this experience Claytor apparently lost interest in doing research at a major university. In 1947 Blackwell invited Claytor to Howard, where he served well until he retired in 1965. In 1980 NAM named the Claytor-Woodard Lecture in his honor.

\section{DAVID BLACKWELL (1919-2010) U. IIIinois AB 1938, MA 1939, PhD 1941}

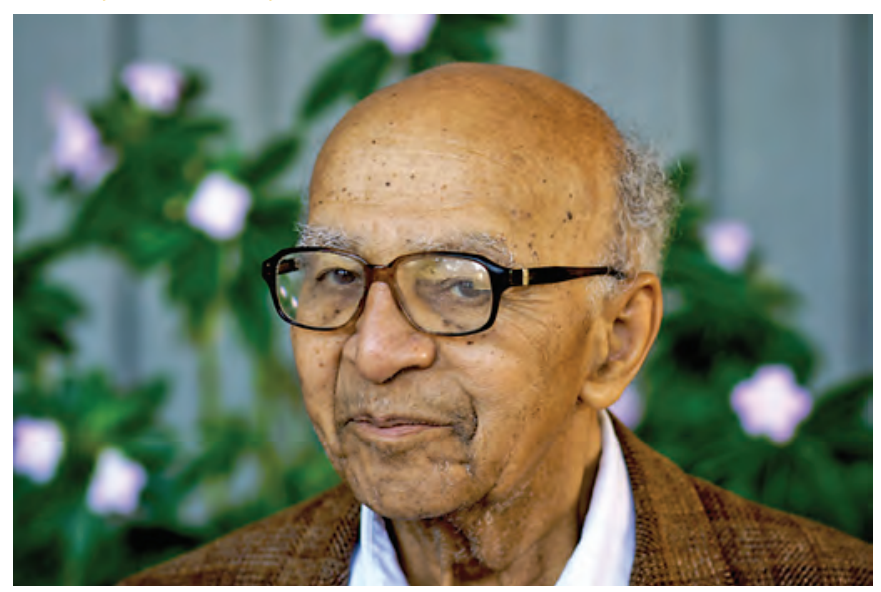

David Blackwell: first Black professor at UC Berkeley, first Black American inducted into the National Academy of Sciences (1965).

David Harold Blackwell took an elementary analysis course as a junior in college and fell in love with mathematics. After earning his $\mathrm{PhD}$ in 1941, he held a one-year postdoctoral fellowship at the Institute for Advanced Study in Princeton. Colleagues in Princeton wished to extend Blackwell's appointment at the Institute; however, the president of Princeton organized a great protest. Blackwell then knew that a white university would not hire him. He applied to all 105 Black Colleges in the country. Blackwell joined the faculty at Howard in 1944 as an instructor. By 1947, he was professor and department chair. Blackwell searched for mathematics around Washington and met $\mathrm{M}$.
A. Girschick of the Department of Agriculture, and they became collaborators in many works. Their 1954 book, Theory of Games and Statistical Decisions, is now a classic. By 1954 Blackwell had published more than twenty papers. He had spent a couple of summers at the RAND Corporation and was visiting professor of statistics at Stanford University from 1950 to 1951. In 1954 he gave an invited address in probability at the International Congress of Mathematicians in Amsterdam. Immediately afterward he was appointed professor of statistics at UC Berkeley. He served for many years as chair of the statistics department before retiring. He produced numerous publications at UC Berkeley and he received many honors and recognitions, including a number of honorary doctorate degrees. He was elected as the first African American to the National Academy of Sciences. David Blackwell is considered to be a world-class African American mathematician, mechanical engineer, and nuclear scientist. NAM named the summer Blackwell Lecture at the MAA MathFest in his honor. In 2002 the Mathematical Sciences Research Institute in Berkeley and Cornell University established the BlackwellTapia Award in honor of Blackwell and Richard A. Tapia, two distinguished mathematical scientists who have been inspirations to more than a generation of African American and Hispanic American students and professionals.

\section{J. ERNEST WILKINS (1923-2011) U. Chicago BS 1940, MS 1941, PhD 1942}

Jesse Ernest Wilkins, initially frequently referred to by the media as the "Negro genius," was a world-class American scientist-mathematician, mechanical engineer, and nuclear scientist. After earning three degrees in mathematics at U. Chicago, Wilkins earned degrees in mechanical engineering from NYU. Wilkins worked as a contributor to the Manhattan Project during World War II, served several important scientific posts with distinction over a half century, and aided in the recruitment of minority students to take mathematics and science courses. Wilkins wrote almost 100 scientific papers (over 55 in mathematics), earning many awards and much recognition. He was the second African American elected to the National Academy of Engineering (1965). He later served as a faculty member at Howard, assisting the mathematics department in establishing in 1975 the first PhD program in mathematics



J. Ernest Wilkins Jr.: earned PhD in mathematics at age nineteen. 
at a Historically Black College or University (HBCU). Coming out of one of his many retirements, Wilkins became Distinguished Professor of Mathematics and Physics at Clark Atlanta University in the late 1990s. In his honor, NAM established a J. Ernest Wilkins Lecture, which is given annually at NAM's fall Undergraduate MATHFest.

\section{ALBERTTURNER BHARUCHA-REID (1927-1985) lowa St. BS 1949}

Albert Turner Bharucha-Reid was an African American research mathematician and probability theorist who worked extensively on probability theory, Markov chains, and statistics. He produced more than 70 papers and six books; his work touched on such diverse fields as economics, physics, and biology. Bharucha-Reid was born Albert Turner Reid in Hampton, Virginia. He studied math and biology at Iowa State

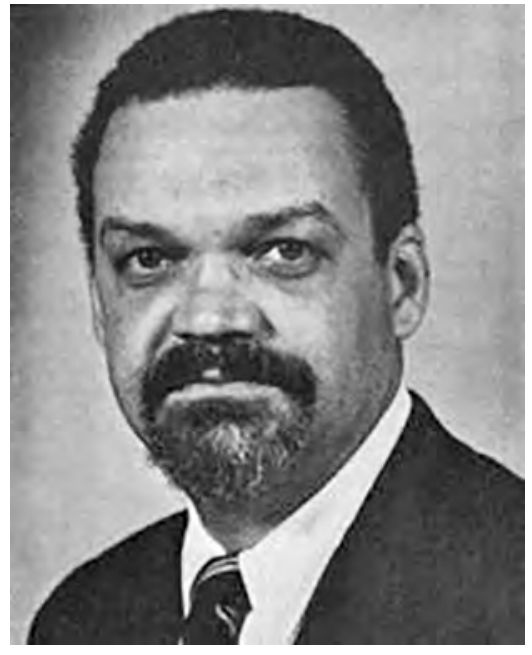
Albert Turner Bharucha-Reid: a world-class African American mathematician who never earned a PhD degree, a great probability theorist who wrote over 70 papers and six books and supervised thirteen PhD students.
NAM named a lectureship in his honor; it is given annually at NAM's Spring Faculty Research-Teaching Conference.

In closing, I invite you to also read about five great African American mathematics teachers:

1. Clarence F. Stephens

2. Marjorie Lee Browne

3. Claude B. Dansby

4. Abdulalim A. Shabazz

5. Etta Z. Falconer

\section{Image Credits}

Woodcut image of Benjamin Banneker is in the public domain. Photo of Edward Alexander is in the public domain. Photo of Elbert Frank Cox is in the public domain.

Photo of Walter Richard Talbot courtesy of Johnny L. Houston.

Photo of Euphemia L. Haynes is in the public domain.

Photo of Dudley Weldon Woodard courtesy of the Moorland-Spingarn Research Center, Howard University Archives.

Photo of William W. Claytor courtesy of Raymond Louis Wilder Papers, Archives of American Mathematics, e_math_02076, Dolph Briscoe Center for American History, University of Texas at Austin.

Photo of David Blackwell courtesy of UC Berkeley.

Photo of J. Ernest Wilkins Jr. by Dan Dry used under terms of the Creative Commons Attribution-Share Alike 3.0 Unported license.

Photo of Albert Turner Bharucha-Reid courtesy of Ronald E. Mickens, Executor of the intellectual properties of the late Prof. Albert Turner Bharucha-Reid.

\section{ABOUT THE AUTHOR}

Johnny L. Houston is cofounder of NAM, author of The History of NAM (2000) and the upcoming American Mathematicians of Diverse Ethnicities (2019), and a NAM Lifetime Achievement Awardee (1999).

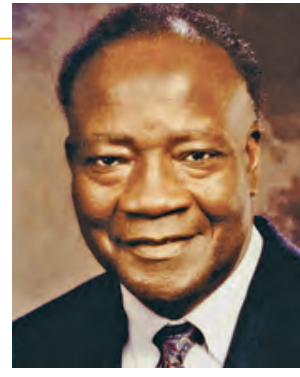

Johnny L. Houston

Phiroze Bharucha, and he legally changed his name to Albert Turner Bharucha-Reid. He taught and lectured in the United States, Europe, and India, holding professorships or research positions at Columbia, UC Berkeley, Oregon, Georgia Tech, Wayne St., the Polish Academy of Science, and Atlanta University (now Clark Atlanta University). In 1970 he was appointed dean of the School of Arts and Sciences at Wayne St., where he graduated his thirteen PhD students. Bharucha-Reid was the editor of about ten international scholarly journals. He bequeathed all of his scientific materials to the Amistad Research Center at Tulane. In May 1984, he was awarded an honorary doctorate of science by Syracuse University. The Citation at Syracuse Commencement stated "We honor you as a founder of Probabilistic Analysis. A mathematician of great distinction, you sensed the importance and glimpsed the possibilities of new developments in your field and then led the way to the applications of new knowledge." This Citation was rather descriptive of much of his life work as a scholar. 


\section{Three Questions: The Journey of One Black Mathematician}

\section{Edray Herber Goins}

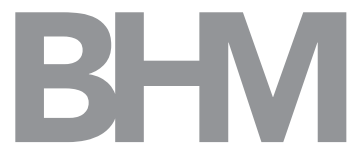

AMC's The Walking Dead features a leader of a group who asks three questions whenever he meets strangers who might possibly join his group. Well, I am the president of the National Association of Mathematicians (NAM), a professional organization that seeks to increase the public awareness of issues of importance to underrepresented minorities in the mathematical sciences, and I would like to modify these questions and ask you the following:

\section{How many African American mathematicians have you graduated?}

How many African American mathematicians have you hired?

Why?

Permit me to take you on a journey of personal growth as I have asked these questions of myself while navigating the mathematical professoriate.

\section{My Undergraduate Days in Pasadena}

She's the terror of Colorado Boulevard / It's The Little Old Lady from Pasadena!

- "The Little Old Lady from Pasadena," The Beach Boys

When I was an undergraduate at the California Institute of Technology, I spent a lot of time wondering about those who looked like me-about African Americans in mathematics, to be precise. I graduated from a predominantly African American high school in Los Angeles in 1990. Yet fifteen miles away in Pasadena there were only 14 Black students in Caltech's freshman class of nearly 180 students. In fact there were fewer than 50 Black students

Edray Goins is professor of mathematics at Purdue University and president of the National Association of Mathematicians. His email address is egoins@purdue.edu.

For permission to reprint this article, please contact: reprint-permission@ams .org.

DOI: http://dx.doi.org/10.1090/noti1637 out of nearly 2,000 undergraduate and graduate students. And there were only 2 Black faculty out of nearly 300 .

I wanted to know: Why were these numbers so low?

As an African American double-majoring in mathematics and physics, I wanted to know whether the numbers were just as low at other universities. In 1992, during my sophomore year, I found out that Stanford University would host the annual National Conference of Black Physics Students (NCBPS). I decided to attend the conference as the sole representative from Caltech, and I was glad that I did. I learned that I wasn't alone as an African American in mathematics and physics. I made friends at that meeting who remain friends to this day. And I met three African Americans at that conference who would become lifelong mentors: Ronald E. Mickens of Clark Atlanta University, Bill Massey of AT\&T Bell Labs, and Sylvester James Gates of the University of Maryland.

But the meeting left me a little confused. There were many capable mathematicians and physicists at this conference-undergraduate students, graduate students, postdoctoral fellows, and faculty. So why were the numbers so small at Caltech?

I asked several faculty about what Caltech had done to recruit faculty over the years. My advisor in physics, Steve Frautschi, told me about the time they tried to hire a young African American physicist from MIT who was a postdoc at Caltech. Unfortunately things didn't work out for several reasons, although he was a pretty successful physicist at the University of Maryland. Frautschi thought it would be great if I met the guy one day. His name was Sylvester James Gates.

So the same person who founded the National Conference of Black Physics Students was almost a Caltech professor? Now I really wanted to learn more. 

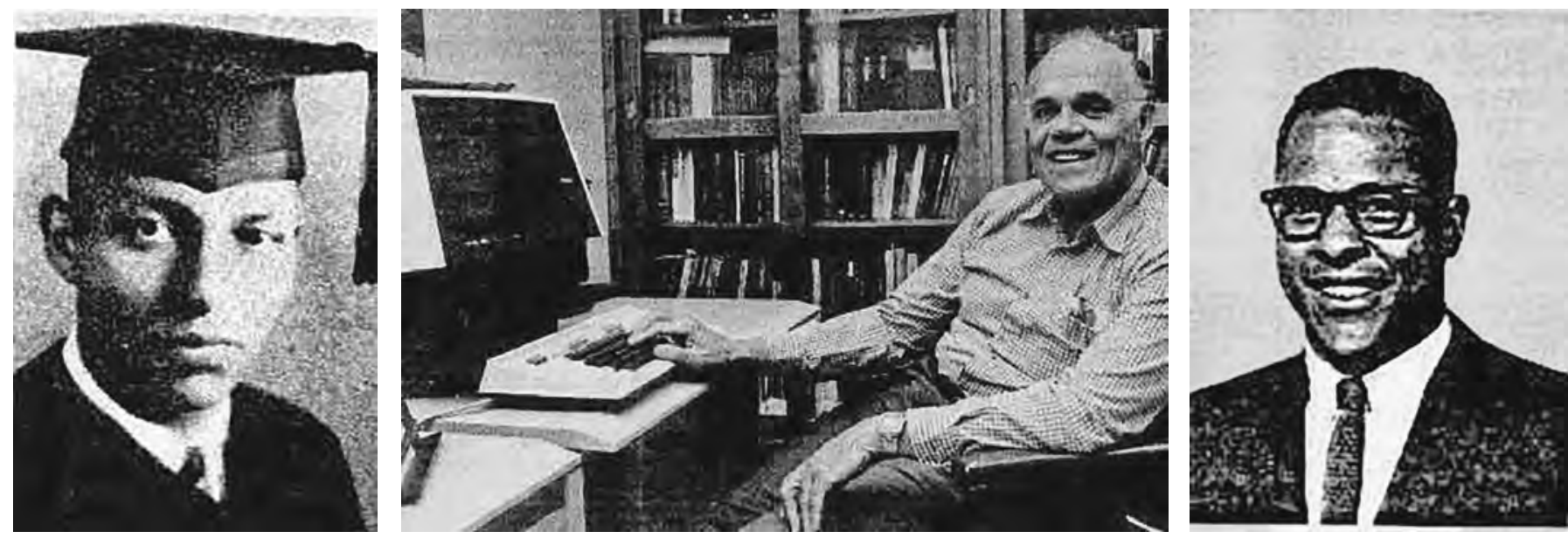

Figure 1. Grant Venerable (BS 1932) was the first African American undergraduate at Caltech. James Lu Valle (PhD 1940) was the first African American graduate student. Charles McGruder (BS 1965) was the second African American undergraduate.

\section{My Brief Stint as a Historian}

The great force of history comes from the fact that we carry it within us, are unconsciously controlled by it in many ways, and history is literally present in all that we do. -James Baldwin

I decided to spend my senior year at Caltech studying the history of African Americans at Caltech. I wanted to know about the first African American undergraduate and graduate students. I wanted to learn more about their experiences, and whether the numbers were always so small.

I had some rather surprising revelations (see Figure 1).

- The first African American undergraduate at Caltech was Grant D. Venerable; he graduated in 1932 with a Bachelor of Science in Civil Engineering.

- The first African American graduate student at Caltech was James Lu Valle; he graduated in 1940 with a Doctorate in Chemistry. In fact, Lu Valle won a bronze medal in the 1936 Olympics in Berlin-yes, the same Olympics where that other African American, Jesse Owens, won a gold medal. The Graduate Student Union at UCLA is named after him, and Morehouse College recently established a fellowship in his honor using funds from Jim Simons.

- The second African American undergraduate at Caltech was Charles Hosewell McGruder; he graduated in 1965 with a Bachelor of Science in Astronomy. There were no other Black undergraduates after Venerable graduated in 1932 until McGruder enrolled in 1961. As fate would have it, I met McGruder at the National Conference of Black Physics Students in 1998, while I was a graduate student.

I also learned that the number of African American students was not always so small. Longtime Caltech employee Lee Browne spent years recruiting students from Los Angeles to attend Caltech. When affirmative action began in earnest in the early 1970s, Browne successfully recruited dozens of African Americans. In fact, the largest

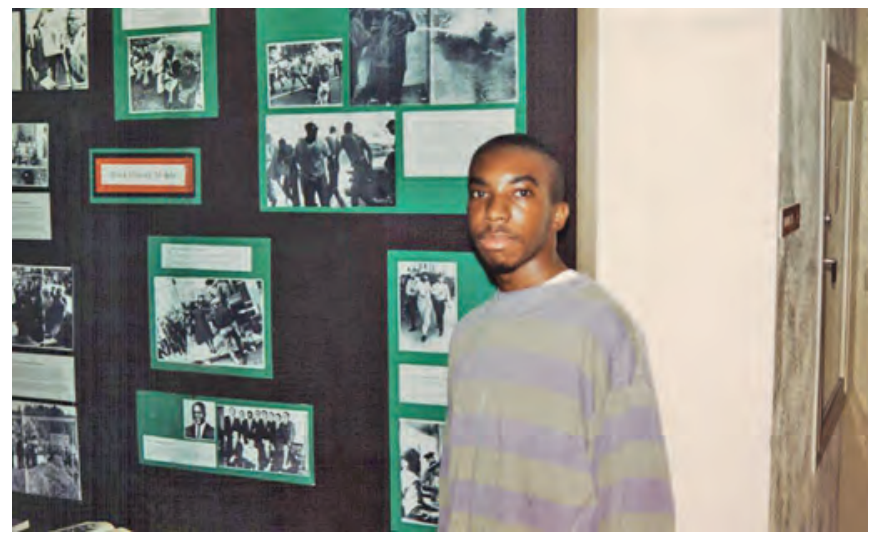

Figure 2. Edray Goins and his Black History Month display at Caltech in 1994.

population of Black students was during the mid 1970s! One of those undergraduates was Robert Thornton, who was my mentor through my scholarship with the American Physical Society (APS). Another was Loretta Carroll, a woman I had known while growing up in Los Angeles. Sadly, I didn't know until I conducted this research that either was a Caltech graduate. In Figure 2 you can see a picture of me next to a prominent display of some of these findings in the Department of Humanities and Social Sciences at Caltech.

With this knowledge, I finally felt connected to a larger community. The numbers of students and faculty were small at Caltech, but there were many others out there with whom I had a historical connection.

\section{Time on the Farm}

We hailin from East Oakland, California and, um Sometimes it gets a little hectic out there But right now, yo, we gonna up you on how we just chill. _-"93 Til Infinity," Souls of Mischief 


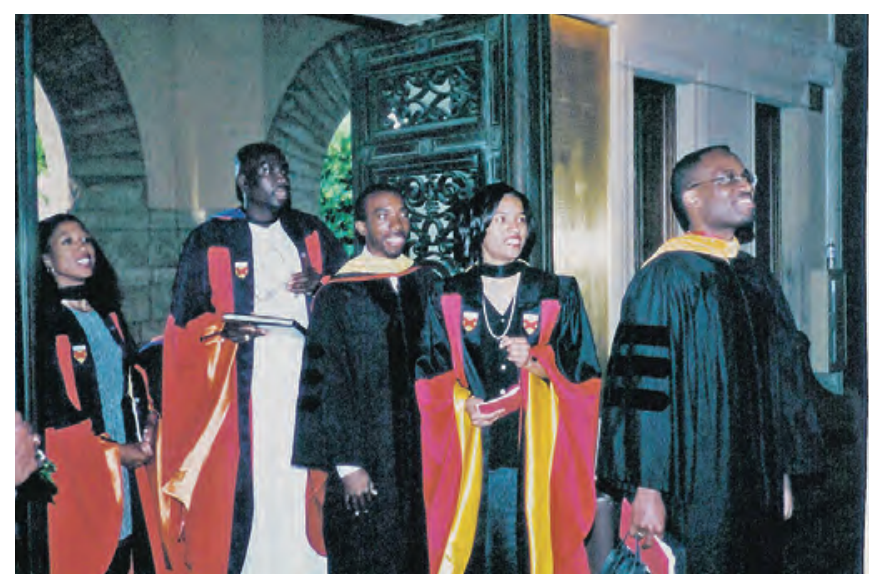

Figure 3. Valerie Nelson, Acha Leke, Edray Goins, Angela Cole, and Duru Ahanotu at Black Graduation at Stanford University in 1999.

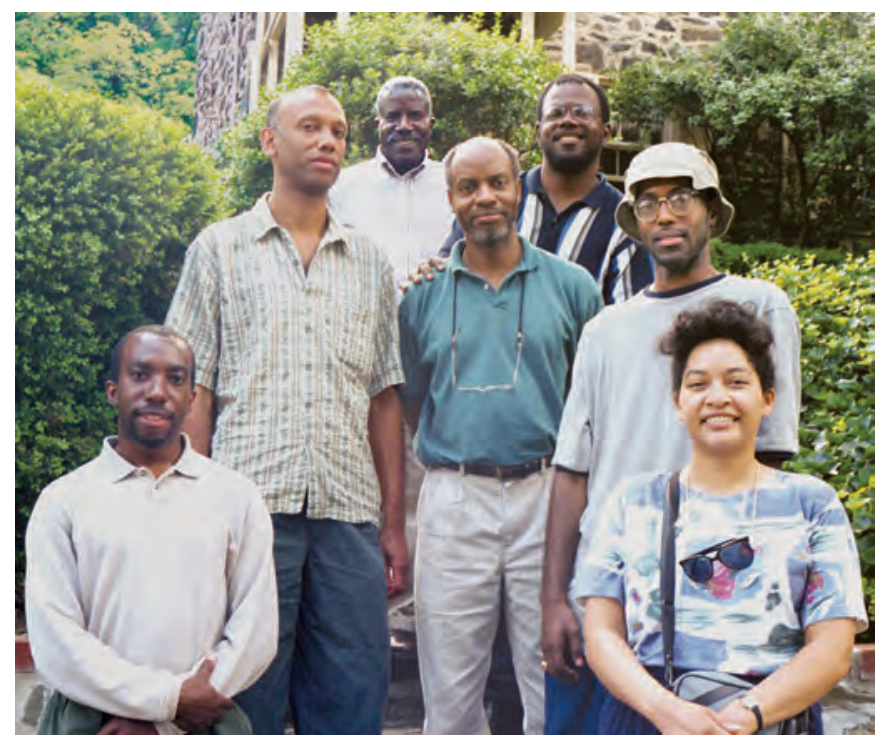

Figure 4. Edray Goins, Carl Graham, Earl Barnes, Mel Currie, Bill Massey, Ahmad Ridley, and Kathy Lewis at CAARMS in 2000 outside the home of Mel Currie.

The 1992 NCBPS meeting at Stanford convinced me that Stanford was where I should pursue my graduate studies. I was a doctoral student in the mathematics department, although I spent a lot of time in the physics department as well. Not surprisingly, the numbers of African American students and faculty at Stanford were very small. I was the only Black student in the mathematics department, and there were no Black professors.

I received a pleasant surprise in my second year at Stanford. The December 1995 issue of the Notices featured a conference for African American mathematicians that had just taken place in Berkeley a few months before. I had mixed feelings: There was a conference for African American Researchers in the Mathematical Sciences (CAARMS)?! How come I didn't know about it until after?!

In the midst of this confusion, I received a phone call one evening. "I'd like to introduce myself," the voice said,
"I am Bill Massey. I started CAARMS." Yes, this was the same person I had met some four years earlier at the NCBPS meeting! "You might be curious to know that I got my doctorate in mathematics from Stanford as well." Massey went on to say there was one other African American to get a doctorate in mathematics from Stanford, so as far as I know there are just three of us now. I may have been the only African American student in mathematics at the time, but I would not be the first African American to graduate from Stanford with a doctorate in mathematics. As proof that I did finish with this degree, Figure 3 shows me and some friends as we marched through Stanford's Black Graduation ceremony.

Once again, I realized that I was part of a larger community than what I was seeing in graduate school. Eventually I would attend many CAARMS conferences and make many more lifelong friends. Figure 4 shows several of us at a later CAARMS in 2000 outside the home of Mel Currie.

\section{Indiana Wants Me}

I'm goin' back to Indiana / Back to where my baby's from I'm goin' back to Indiana / Indiana here I come.

_-"Goin' Back to Indiana," The Jackson 5

By the time I accepted my first tenure-track position at Purdue University, I had nearly resigned myself to the idea that I would just be one of a handful of African Americans in my mathematics department. Still, part of me realized I had to do something to change this.

So I went out to recruit my own African American graduate students. My first graduate student was Kevin Muriithi Mugo, who graduated from Purdue in 2014 (see Figure 5). We met while working together during an NSF-funded REU at Miami University called the Summer Undergraduate Mathematical Sciences Research Institute. I was so impressed by the success Miami University had in recruiting women and underrepresented minorities for their REU that recently I started my own REU titled the Purdue Research in Mathematics Experience (PRiME).

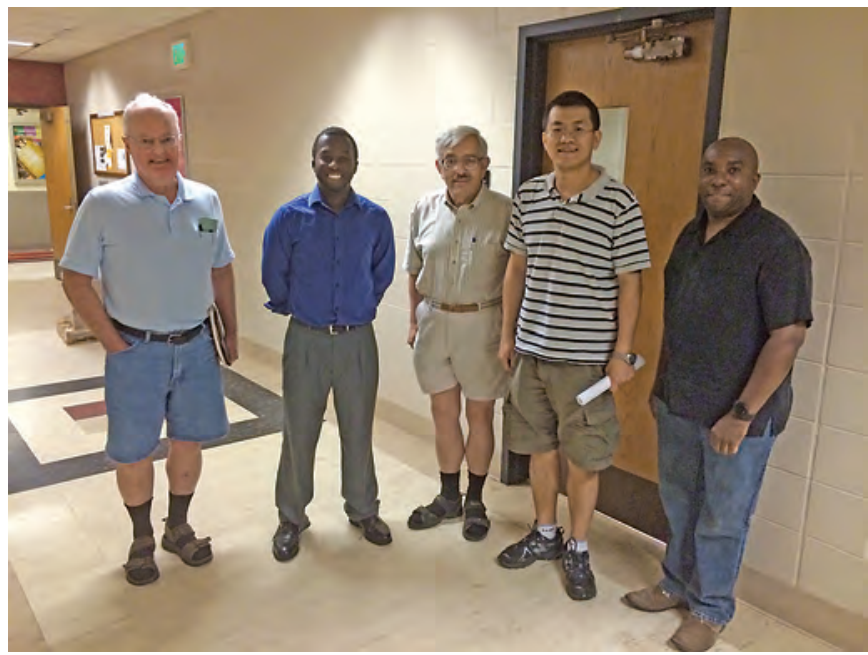

Figure 5. Bill Heinzer, Kevin Muriithi Mugo, Sam Wagstaff, Tong Liu, and Edray Goins after Kevin's thesis defense in summer 2014. 


\section{I'm still looking for answers.}

But I began to wonder much as I had done while an undergraduate: What about the history of African Americans at Purdue? I wanted to know about the first African American graduate students in the mathematics department.

As I tried to ask around Purdue, I realized no one kept records of every African American to come through the math department. Fortunately, one of the first graduates is my mentor as president of NAM, and he had been collecting this information on his own for years! We both discovered that there have been seven African Americans to graduate with a doctorate in mathematics from Purdue:

- Melvin L. Heard, who is now associate professor of mathematics and assistant dean in the College of Liberal Arts at the University of Illinois at Chicago (UIC), finished in 1967 under Robert Arnold Gambill and Merritt S. Webster.

- Benjamin Joseph Martin, who is now head pastor at St. Rest Baptist Church, finished in 1969 under Thomas Wilson Mullikin.

- Johnny L. Houston, who is now emeritus professor of mathematics at Elizabeth City State University (ECSU), finished in 1974 under Eugene V. Schenkman.

- Kathy Marie Lewis, who is now associate professor of mathematics at Morehead State University, finished in 1999 under Carl Cowen.

- Sean Colbert-Kelley, who is now a scientist at the National Institute of Standards and Technology (NIST), finished in 2012 under Daniel Phillips.

- Kevin Muriithi Mugo, finished in 2014 under me.

- Reginald L. McGee, who is now a postdoctoral fellow at the Mathematical Biosciences Institute (MBI), finished in 2015 under Gregery T. Buzzard.

\section{Semper Adquilirens}

Now that I am a full professor at Purdue University, I spend a lot of time pondering the three questions that began this article. How many African American mathematicians have you graduated? My department has graduated seven with doctorates in mathematics, while I have graduated just one. How many African American mathematicians have you hired? Sadly none have been hired as tenure-track during my years at Purdue, although we did hire one as a postdoctoral fellow for three years. Why? I don't know exactly. I have tried to recruit many, many African American students and faculty to Purdue in the thirteen years I've been on the faculty. I'm still looking for answers.

I'm still amazed that, after all of these years, I look to Jim Gates, Bill Massey, and Ronald E. Mickens for advice and inspiration. As president of NAM, I was honored to have Jim Gates serve on our annual NAM Panel Discussion at the 2017 Joint Mathematics Meetings in Atlanta (see Figure 6). As a director of an NSF-funded REU, I was thrilled to have my own undergraduates meet Bill Massey at the 23rd annual CAARMS at the University of Michigan in 2017. And as a lover of mathematics, I am looking forward to watching Ronald Mickens speak at the 2018 Joint Mathematics Meetings in San Diego as NAM's Claytor-Woodard Lecturer.

And yes, I'm still asking them the Three Questions.

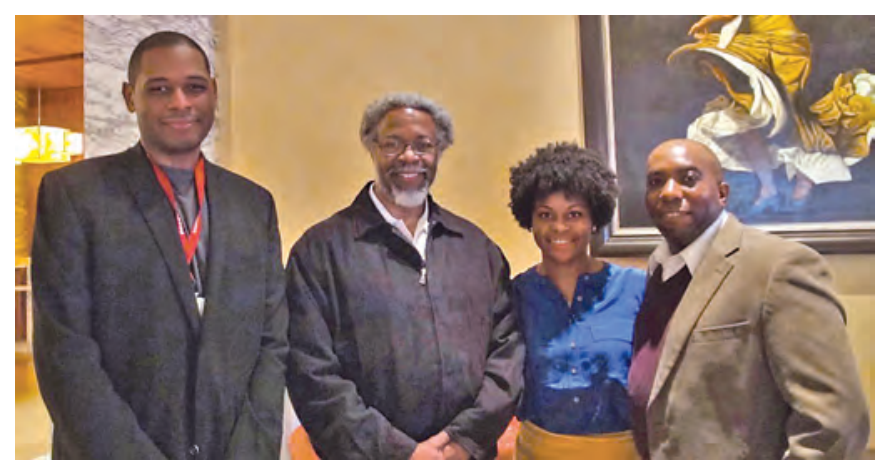

Figure 6. Cory Colbert, Jim Gates, Ebony Harvey, and Edray Goins at the 2015 Joint Mathematics Meetings in San Antonio, Texas.

\section{Photo Credits}

Figure 1, photo of Grant Venerable from the California Institute of Technology Big T, 1932.

Figure 1, photo of James Lu Valle from Stanford University, Campus Report, January 8, 1984.

Figure 1, photo of Charles McGruder from the California Institute of Technology Big T, 1965.

Figures 2-6, and the author photo from the personal collection of Edray Goins.

\section{ABOUT THE AUTHOR}

Edray Goins has been working on properties of Selmer groups for elliptic curves using class groups of number fields, as well as properties of Dessins d'Enfants. He runs an REU that focuses on understanding properties of Belyi maps, and he maintains his own blog about Dessins d'Enfants.

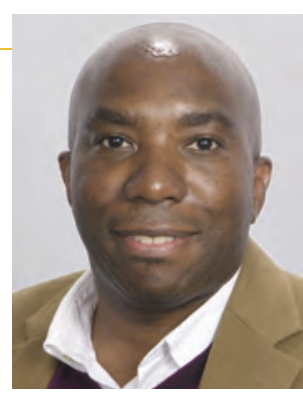

Edray Goins 


\section{Personall Conclusions}

\section{Talithia Williams, Guest Editor}

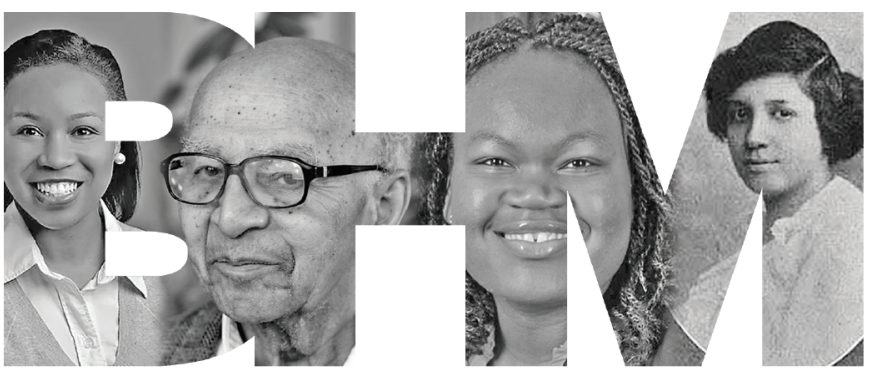

Growing up in Columbus, Georgia, I never dreamed I would one day get a $\mathrm{PhD}$ in statistics. My AP Calculus teacher, in a casual conversation after class one day, nonchalantly mentioned that he thought I was good in math and should think about majoring in it. I didn't love math. I didn't love any subject. But my mind has forever attached itself to that memory, not because of the words he shared with me, but because it came from someone who looked so different from me. Mr. Dorman was a middle-aged white man, and my 17-year-old brain saw no reason why he chose to affirm me in that moment. He didn't have anything to gain. But his comment was powerful. Major in math? When I go to college? Did he really think I could do mathematics?

I didn't become aware of any African American women mathematicians until I went off to Spelman College, where several were on the faculty. Only later did it occur to me that this was an anomaly. There's a subtle, indescribable confidence that comes from being taught by a person who looks like you. At Spelman, I could be anything. A Sylvia Bozeman. An Etta Falconer. If I failed an exam, it wasn't because I was Black. It wasn't because I was a woman. In fact, from my vantage point, being a Black woman should make me excel in math, just like the faculty that taught me. I chose graduate school in mathematics at Howard University because I wanted that same supportive environment. Two statistics courses later, I found myself loving data.

I transferred to Rice University to finish a $\mathrm{PhD}$ in statistics and was the only woman and only African American in my class. The Asian, Indian, Russian, and white male students all had a group. I had...myself. Rarely is one successful in graduate school without a group, so I leaned on my EDGE cohort for support. I'd spent the summer of 2000 learning graduate-level mathematics with a group of
14 women at Bryn Mawr College. They became my virtual group. After finishing my PhD, I excitedly went off to work with the talented students at Harvey Mudd College, eventually becoming the first African American woman to ever receive tenure at the institution.

My decision to attend Spelman, a historically Black college for women, would forever change my attitude towards mathematics. My professors (Sylvia Bozeman, Etta Falconer, Jeffrey Ehme, Colm Mulcahy, Fred Bowers, Nagambal Shah, Yewande Olubummo, Gladys Glass) invited me to the mathematical table and found a place for me in the mathematical community. Although Historically Black Colleges and Universities (HBCUs) enroll only 10 percent of all African American students, they produce over 30 percent of all baccalaureate degrees in mathematics and statistics and produced 32 percent of the African American baccalaureates who eventually earned doctoral degrees in mathematics from 2004 to 2008. Like the Math Alliance, EDGE, and NAM, we must find ways to partner with minority-serving institutions to shepherd today's students into the beautiful world of mathematics.

\section{Photo Credit}

Photo of Talithia Williams courtesy of Harvey Mudd College.

\section{ABOUT THE EDITOR}

Renowned for her popular TED Talk, "Own Your Body's Data," Talithia Williams uses statistics to communicate the beauty of mathematics and excite people about data. She is cohost of the upcoming PBS series NOVA Wonders, premiering in April 2018, and shares her life with an amazing husband and three energetic boys. 